\title{
The origin and maturation of lagoonal glauconites: a case study from the Oligocene Maniyara Fort Formation, western Kutch, India
}

\section{SANTANU BANERJEE ${ }^{1}$, SHOVAN LAL CHATTORAJ ${ }^{1}$, P.K. SARASWATI ${ }^{1}$, SOMNATH DASGUPTA ${ }^{2}$, URBASHI SARKAR ${ }^{1}$ and ADAM BUMBY ${ }^{3}$}

1. Department of Earth Sciences, Indian Institute of Technology Bombay, Powai, Mumbai-400076, India

2. Indian Institute of Science Education \& Research, DC 35/1, Sector 1, Salt Lake, Kolkata-700064, India

3. Department of Geology, University of Pretoria, Pretoria 0002, South Africa

* Corresponding author: Santanu Banerjee, Department of Earth Sciences, Indian

Institute of Technology Bombay, Powai, Mumbai-400076, India.

Email:santanu@iitb.ac.in

$* * * * * * * * * * * * * * * * * * * * * * * * * * * * * * * * * * * * * * * * * * * * * * * * * * * * * * * * * * * * * * * * * * * *$

An integrated study of the sedimentology, micropalaeontology, mineralogy and geochemistry of glauconites in the Oligocene Maniyara Fort Formation (western Kutch, India), has been undertaken. Authigenic glauconites, mostly of evolved type, formed within a back-barrier lagoonal environment. Foraminifera help constrain the biostratigraphy and along with sedimentological evidence, provide information on the depositional conditions. Glauconite in the Maniyara Fort Formation occurs either as infillings within intra-particle pores of larger foraminifers, or as an altered form of faecal pellets. X-Ray diffraction studies reveal the less mature nature of glauconite infillings compared to the glauconite pellets. Electron microprobe investigation confirms a relative enrichment of $\mathrm{K}_{2} \mathrm{O}$ and total $\mathrm{Fe}_{2} \mathrm{O}_{3}$ in the latter. Both varieties of glauconite formed by initial authigenic precipitation of K-poor glauconite and subsequently matured by addition of potassium in the interlayer sites and fixation of total iron in the octahedral sites; calcium, magnesium and aluminum were released from the glauconite structure concomitantly. Alkaline conditions during the entire process of glauconite formation did not allow dissolution of foraminiferal tests. Mineralogical and chemical characteristics of the Maniyara Fort Formation glauconites are more similar to deep marine glauconites than those reported from other shallow or marginal marine settings. A low negative cerium anomaly, as well as abundant pyrite, suggests formation of glauconite in sub-oxic micro-environments, created by decay of organic matter associated with foraminiferal 
chambers and faecal pellets. Sub-oxic condition apparently prevailed relatively longer within the Maniyara Fort Formation lagoons.

KEY WORDS lagoonal glauconites; infillings; faecal pellet; foraminifers; glauconite maturity; cerium anomaly; Oligocene; India

\section{INTRODUCTION}

Faecal pellets and bioclasts are common substrates for glauconite formation in Phanerozoic sediments (Takahashi, 1939; Ehlmann et al., 1963; Porrenga, 1967; McRae,

1972; Bjerkeli and Östmo-Saeter, 1973; Birch et al., 1976; Chafetz, 1979; Odin and Matter, 1981; Rao et al., 1993; Stille and Clauer, 1994; Kelly and Webb, 1999; Chafetz and Reid, 2000; Giresse and Wiewióra, 2001; El Albani et al., 2005; Wigley and Compton, 2007). The chemical reactions that turn faecal pellets into glauconites are simple compared to the reactions involved in the glauconitization of bioclasts, as pellets are often rich in the elements necessary for the formation of glauconite (Chafetz and Reid, 2000). Submarine low-energy conditions (varying in depth between 50 and $500 \mathrm{~m}$ ) promote the formation of glauconite (Odin and Matter, 1981; Amorosi, 2003). However, glauconite may form in lagoons, tidal flats, lakes and under subaerial conditions (Huggett and Cuadros, 2010; see also Van Houten and Purucker, 1984; Cudzil and Dreise, 1987; Dasgupta et al., 1990; Huggett and Gale, 1997; Chafetz and Reid, 2000; Gonzalez et al., 2004; El Albani et al., 2005; Meunier and El Albani, 2007). The origin, evolution, depositional and stratigraphical significance of glauconites may thus vary widely (Chafetz and Reid, 2000; El Albani et al., 2005). Therefore, a better perspective of the natural controls on the process of glauconitization may arise from an integrated micropalaeontological, sedimentological, mineralogical and chemical investigation. With this goal in mind, this paper attempts to understand the origin, maturation and evolution of the glauconite formed within foraminiferal tests and faecal pellets of the Oligocene Maniyara Fort Formation in western Kutch, India in a holistic perspective. Though the biostratigraphy of the Palaeogene succession in Kutch is well documented, sedimentological studies are rare (Singh, 1978; Saraswati and Banerji, 1984; Chattoraj et 
al., 2009). The depositional environment of the Maniyara Fort Formation is interpreted here using combined sedimentological and micropalaeontological data, and the mineralogical and chemical characteristics of the glauconites present in the Formation are interpreted in the backdrop of the depositional setting of the Maniyara Fort Formation.

\section{GEOLOGICAL BACKGROUND}

\subsection{Stratigraphy of the study area}

Palaeogene and Neogene sediments are exposed for about $3000 \mathrm{~km}^{2}$ to the south of the Rann of Kutch in western India (Figure 1). The Palaeogene sedimentary succession unconformably overlies the Deccan Traps (age 69 - 63 Ma; Pande, 2002) and Jurassic sedimentary strata, and is composed of a mixed carbonate-siliciclastic succession. Biswas (1992) subdivided the entire Palaeogene succession of Kutch into five formations, viz., Matanomadh, Naredi, Harudi, Fulra Limestone and Maniyara Fort formations (Table 1). The non-marine Palaeocene Matanomadh Formation at the base of the succession is completely devoid of foraminifers, while all the overlying formations contain abundant shallow marine foraminifers (Biswas, 1992).

The Oligocene Maniyara Fort Formation unconformably overlies the Fulra Limestone and is, in turn, unconformably overlain by the Miocene Khari Nadi Formation (Biswas, 1992; Kumar et al., 2009; Table 1). The Palaeogene strata in western Kutch, in general, are tectonically undisturbed, and have a very gentle dip $\left(<3^{\circ}\right)$ towards SSW. The basal contact of the Maniyara Fort Formation with the underlying Fulra Limestone is distinctly marked by a regionally extensive palaeokarst surface, recognized as an unconformity. Biostratigraphically, this boundary coincides with the abrupt disappearance of the typical Middle Eocene larger foraminiferal assemblage of which Nummulites beaumonti, $N$. cuvillieri and $N$. discorbinus abound in the Fulra Limestone (Saraswati et al., 2000). The upper contact of the Maniyara Fort Formation represents another unconformity marked by a distinct break in the biostratigraphic succession (Raju, 1974; Biswas, 1992; Kumar et al., 2009). Biswas (1992) subdivided the Maniyara Fort Formation into four members, viz., Basal, Lumpy Clay, Coral Limestone and Bermoti 
members (Table 1). Biswas (1992) used the exposures near Bermoti village (Figure 1) as the type section that exposes all four of the defined members. The intensely bioturbated Lumpy Clay Member is, however, a local variance of the Basal Member. The Basal Member consists of nummulitic limestone, glauconite-bearing green shale and red shale. The Coral Limestone Member consists of Lepidocyclina-bearing limestones, often enclosing irregularly-shaped and laterally limited coral bioherms (up to $1.1 \mathrm{~m}$ thick); the bioherms appear as patch-reefs that possibly dotted the lagoon forming behind a coral reef offshore (Ghose, 1982). The Bermoti Member is characterized by Spiroclypeus and Heterostegina-bearing limestone, grey shale and siltstone.

In the study area near Kunrajpur $\left(23^{\circ} 43^{\prime} 28.8^{\prime \prime} \mathrm{N}, 68^{\circ} 43^{\prime} 43.2^{\prime \prime} \mathrm{E}\right)$ only two of the Palaeogene Formations, viz., the Fulra Limestone (av. thickness $80 \mathrm{~m}$ ) and the Maniyara Fort Formation (av. thickness $20 \mathrm{~m}$ ) are exposed. The present paper focuses upon the Maniyara Fort Formation, three members of which viz., the Basal, Coral Limestone and Bermoti are present in the studied section. The Lumpy Clay Member, a variance of the Basal Member, is absent in the studied section. The base of the Maniyara Fort Formation is marked by the appearance of Nummulites fichteli, an early Oligocene biozonal species (Figure 2). The upper contact of the Maniyara Fort Formation with the Khari Nadi Formation is, however, poorly exposed in the study area. The presence of $N$. fichteli in the Basal Member and the occurrence of $N$. fichteli, Lepidocyclina (Eulepidina) ephippioides and Lepidocyclina (Nephrolepidina) isolepidinoides in the Coral Limestone Member establishes an early Oligocene age, equivalent of the Rupelian Stage, to these two members of the Maniyara Fort Formation (Saraswati, 1995). The Bermoti Member, on the other hand, contains Spiroclypeus ranjanae, Miogypsina (Miogypsinoides) complanata and M. (M.) formosensis. Accordingly a late Oligocene age corresponding to the Chattian Stage is assigned to the Bermoti Member (Raju, 1974) (Table 1).

\subsection{Maniyara Fort Formation: facies and depositional environments}

Four distinct lithofacies, viz., limestone, red shale, green shale and grey shale comprise the Maniyara Fort Formation that recur at different stratigraphic levels (Fig. 2). The 
limestone lithofacies occurring at the base, middle and top of the Formation is very rich in foraminifers, constituting up to $90 \%$ of the sediment volume. Well-preserved Nummulites ranging in diameter from a few $\mathrm{mm}$ to $2 \mathrm{~cm}$ abound and small-scale crossstratification is locally present within it. The cross-set thickness varies between $10-15$ $\mathrm{cm}$ (Figure 3A, B). The facies occurs at three different stratigraphic levels. Its lowest unit overlies the regionally extensive palaeokarst surface defining the base of the Formation and is often topped by local palaeokarst surfaces (Figure 3C). The red shale lithofacies that alternates with the green shale facies, at its lowest level overlies the palaeokarst surfaces (Figure 3D). This facies is barren of foraminifers, but contains leaf impressions and rootlets and often exhibits desiccation cracks. On the other hand, foraminiferal tests are common within the green shale and its colour is imparted by the abundance of glauconite pellets (Figure 3D). The grey shale lithofacies, nevertheless, has the highest content of benthic foraminifers (Figure 2). Burrows, dominantly vertical in attitude, are common within all but the red shale facies (Figure 2).

The aforementioned facies characteristics strongly support the previous lagoonal interpretation of the Maniyara Fort Formation, behind a wave barrier, possibly a coral reef as suggested by previous workers (Ghose, 1982; Biswas and Deshpande, 1983; Biswas, 1992; Kumar and Saraswati, 1997). The combined foraminiferal and lithofacies study suggests that the red shale represents a marginal part of the lagoon and the green shale represents a relatively deeper part of the lagoon corresponding to $10-15 \mathrm{~m}$ of water depth. The grey shale facies, characterized by the highest abundance and diversity of benthic foraminifers possibly formed in the deepest part of the lagoon and corresponds to $20-30 \mathrm{~m}$ of water depth. The cross-stratified limestone facies suggests deposition in a seaward position, possibly in proximity to an offshore barrier envisaged earlier. The overall sedimentary succession reflects a transgressive column representing a backbarrier lagoon complex.

\section{METHODS AND MATERIALS}


The samples were collected from the outcrops near Kunrajpur village (Figure 1). The lithology and stratigraphic positions of the samples are shown in Figure 2. Variations in the relative proportions of foraminiferal genera were used to estimate water-depth and reconstruct the palaeobathymetric curve (Figure 2). To estimate water-depth for glauconites in the present study, quantitative foraminiferal data for palaeobathymetric reconstruction were obtained by sorting from approximately 30 gm of processed samples. The glauconite-bearing shale and limestone were used for preparation of thin sections and XRD. Petrography was carried out using a Leica DM 4500P polarizing petrographic microscope attached to a Leica DFC420 camera. Glauconite was separated from quartz, calcite and other minerals using a Nikon SMZ645 stereozoom microscope for mineralogical and chemical analysis. For XRD analysis, clay suspensions made from acid treated $(10 \% \mathrm{HCl})$ glauconite-bearing fossils and individual pellets of glauconites were mounted as slurries on glass slides (Jackson, 1979). The air-dried, powdered samples were scanned by Rigaku Geigerflex X-ray Diffractometer from $3^{\circ}$ to $60^{\circ} 2 \theta$ at $0.5^{\circ}$ $2 \theta /$ min scan speed using nickel filtered Copper $\mathrm{K}_{\alpha}$ radiation at the Department of Earth Sciences, IIT Bombay. The samples were subsequently scanned after treating with ethylene glycol $\left(100^{\circ} \mathrm{C}\right.$ for 1 hour) and finally scanned after heating to $490^{\circ} \mathrm{C}$ for 2 hours under the same instrumental settings. The chemical composition of glauconite pellets was determined using a CAMECA SX-100 Electron Probe Micro Analyser (EPMA) at the National Geophysical Research Institute (NGRI), Hyderabad, using synthetic orthoclase $(\mathrm{K}, \mathrm{Al})$, wollastonite $(\mathrm{Ca}, \mathrm{Si})$, periclase $(\mathrm{Mg})$, albite $(\mathrm{Na})$ and haematite $(\mathrm{Fe})$ as standards. The operating conditions for the EPMA were $15 \mathrm{kV}$ accelerating voltage with specimen current of $40 \mathrm{nA}$ and beam diameter of $1 \mu \mathrm{m}$ (peak: 10-20s and background counting: 510s). Analysis points were selected with the help of reflected light microscopy and BSE images and the data were ZAF corrected.

Trace element and rare earth element (REE) concentrations in glauconite samples were measured using a PerkinElmer Sciex ELAN DRC II ICPMS at NGRI, Hyderabad. Cleaned glauconite pellets of each sample were suspended into bromoform diluted by appropriate proportion of ethyl alcohol. The separated pellets were split into heavy and light weight fractions (cf. Jarrar et al., 2000). $0.3 \mathrm{~g}$ of each sample was digested by a mixture of 5:4:1.5 $\mathrm{HF}, \mathrm{HNO}_{3}$, and $\mathrm{HClO}_{4}$ at $120^{\circ} \mathrm{C}$ in a platinum crucible for 8 hours. 
The acids were completely evaporated at $160^{\circ} \mathrm{C}$ and the residue was dissolved in $10 \mathrm{ml}$ of $5 \mathrm{~N} \mathrm{HCl}$. REE were analyzed after separation using Ag50WX12 and Ag50WX8 sulphonated polystyrene cation exchanger in hydrogen form following the procedure described by Zachmann (1988) and Jarrar et al. (2000). USGS geochemical reference standard MAG-1 and SCo-1 were used to assess the accuracy of the analyses.

\section{MODE OF OCCURRENCE OF GLAUCONITE}

Glauconite in the Maniyara Fort Formation occurs in two different forms, as an altered form of faecal pellets (referred to hereafter as glauconite pellets), and as infilling in foraminiferal chambers (referred to hereafter as glauconite infilling) (Figure 4). Both glauconite pellets and infillings occur within the green shale, grey shale and limestone lithofacies shown in Figure 2. The green shale lithofacies exhibits the highest concentration of glauconite pellets, comprising about $65 \%$ of total sediment volume. In grey shale and limestone facies the pellets may comprise up to $20 \%$ by volume. The red shale is completely devoid of glauconite.

The glauconite pellets concentrate along certain laminae within the green shale, although remaining enclosed by a clay matrix. The pellets are, more or less, sphaerical in shape, exhibit a smooth surface texture and appear brownish green under plane-polarised light and dark green under crossed-polars. The pellets exhibit deeply penetrating radial cracks which are usually filled with iron oxides (Figure 4A). Glauconite pellets characteristically exhibit a densely packed aggregate texture consisting of a random arrangement of micro-platelets with pinpoint extinction (Figure 4B). An iron oxide coating is observed locally on glauconite pellets and that may, in places, be further rimmed by glauconitic overgrowth (Figure 4B, C). Disseminated pyrite is a common associate in the glauconite pellets, occurring as $100-500 \mu \mathrm{m}$ size aggregates of microcrystals or as individual euhedral crystals (Figure 4C, D). Pyrite is rare in the case of glauconite infillings. Glauconite infillings occur within the chambers of foraminiferal tests (mostly Nummulites) and appear light brownish green under plane polarized light (Figure 4E, F). 
An authigenic origin of the glauconite pellets is indicated by the presence of deeply penetrating cracks with matching boundaries on the grain surface (Bandyopadhyay, 2007). The glauconite infillings within the chambers of intact foraminifers further corroborate an autochthonous origin of glauconite.

\section{RESULTS OF MINERALOGICAL AND GEOCHEMICAL ANALYSIS}

\subsection{X-ray diffraction studies}

X-ray diffraction studies were carried out on glauconite pellets and infillings separately to reveal the differences in mineralogy. Air-dried samples of both varieties exhibit characteristic (001), (020) and (131) reflections of glauconitic minerals (Figure 5). Untreated glauconitic pellets exhibit the (001) basal reflection at $10 \AA$ with subdued intensity and relatively asymmetric shape (Figure 5A). The peaks appear sharper after glycolation and heating (Figure 5B,C). The other characteristic peaks of untreated samples viz, $4.5 \AA(020), 3.33 \AA$ (003) and $2.5 \AA$ (131) remains unaffected after glycolation and heating (Figure 5B, C). Air-dried samples of glauconite infillings exhibit a relatively more subdued basal refection (Figure 5D). On glycolation, the 001 reflection of glauconite infilling exhibits peak separation (Figure 5E) and is represented by a symmetrical, solitary $10.27 \AA$ peak that remains unchanged on heating (Figure 5F).

A sharp, symmetrical basal reflection is reported by Odin and Matter (1981) at $10 \AA$ A. However, they considered that the first-order basal reflection may be recorded anywhere between $10 \AA$ to $14 \AA$. Negligible shifts in the peak from basal reflection upon glycol and subsequent heat treatment reflect a less pronounced inter-stratification of expandable and non-expandable layers in the glauconite phase (Thompson and Hower, 1975). The peaks correspond to glauconites sensu stricto of McRae (1972). The minor 15 $\AA$ montmorillonite peak indicates the presence of smectite impurities in the case of infillings (Figure 5D-F). Kaolinite (7.1 $\AA$ ) also occurs as impurities and is detected in airdried and glycolated samples (Figure 5A, B, D, E). The kaolinite peak is substantially reduced after heating (Figure $5 \mathrm{C}, \mathrm{F}$ ).

Odin and Matter (1981) considered four stages of evolution of glauconitic grains based on potassium content, ranked as nascent $\left(<4 \% \mathrm{~K}_{2} \mathrm{O}\right)$, slightly evolved $\left(4-6 \% \mathrm{~K}_{2} \mathrm{O}\right)$, 
evolved $\left(6-8 \% \quad \mathrm{~K}_{2} \mathrm{O}\right)$ and highly evolved $\left(8-10 \% \mathrm{~K}_{2} \mathrm{O}\right)$. The relationship between diffractometrical parameters and glauconite maturation has been explored by many workers (Odin and Matter, 1981; Kim and Lee, 2000; Pasquini et al., 2004; Amorosi et al., 2007). Odin and Matter (1981) established an estimate of the d (001) value, expressed as the distance between 001 and 020 reflections. This value approximates to the position of the (001) peak (Amorosi et al., 2007). A decreasing full width at half maximum value (FWHM) of the basal (001) reflection is found to be a more powerful tool for estimation of glauconite maturity (Amorosi et al., 2007). Figure 6 presents the relationship between the diffractometrical parameters and the $\mathrm{K}_{2} \mathrm{O}$ content of glauconites. The results are similar to the deep marine glauconites reported by Amorosi et al. (2007). The d (001) value of the glauconite samples steadily decreases from 13.3 to $12.3^{\circ} 2 \theta$ while the $\mathrm{K}_{2} \mathrm{O}$ value increases from $5.6 \%$ to $7.2 \%$ (Figure 6). This is accompanied by a steady decrease of the FWHM value from $0.97^{\circ}$ to $0.71^{\circ} 2 \theta$. Therefore, both the FWHM and $\mathrm{d}(001)$ values prove to be important parameters for the estimation of glauconite maturation. Both varieties of glauconites correspond to glauconitic mica of Odin and Matter (1981). The infillings exhibit a relatively broader and less symmetrical basal reflection compared to the pellets, suggesting their less mature nature. Based on $\mathrm{K}_{2} \mathrm{O}$ content the infillings are considered as K-poor glauconite.

\subsection{Major and minor element characteristics}

EPMA data of both varieties of glauconites are presented in Table 2. Major element compositions of the lagoonal glauconites are comparable to those reported from deep marine environments (see Amorosi et al., 2007). The $\mathrm{K}_{2} \mathrm{O}$ content of the glauconite varies from $5.6 \mathrm{wt} \%$ to $7.2 \mathrm{wt} \%$ (av. $6.8 \mathrm{wt} \%$ for pellets, av. $6.1 \mathrm{wt} \%$ for infillings). Except for two glauconite infillings, the $\mathrm{K}_{2} \mathrm{O}$ content of the glauconites correspond to the evolved type (Odin and Matter, 1981; Amorosi, 1997). Total $\mathrm{Fe}_{2} \mathrm{O}_{3}$ values of the samples vary from $23.4 \mathrm{wt} \%$ to $28 \mathrm{wt} \%$. Total $\mathrm{Fe}_{2} \mathrm{O}_{3}$ content of glauconite pellets are slightly higher (av. $26.6 \mathrm{wt} \%$ ) than that of the glauconite infillings ( $24.8 \mathrm{wt} \%$ ). The average total $\mathrm{Fe}_{2} \mathrm{O}_{3}$ and $\mathrm{MgO}$ content of the glauconites are on the higher side compared to the published values (Odin and Matter, 1981; Jarrar et al., 2000; Amorosi et al., 2007). CaO 
content of the glauconites are lower (ranging from $0.3 \mathrm{wt} \%$ to $0.6 \mathrm{wt} \%$, av. $0.5 \mathrm{wt} \%$ ) than those reported by Amorosi et al. (2007). $\mathrm{MgO}$ and $\mathrm{CaO}$ values are slightly lower in glauconite pellets compared to the glauconite infillings (Table 2).

Variation in major element composition is reflected in the atomic structure of the glauconites. The average structural formula for the glauconite pellets is:

$\left(\mathrm{K}_{0.63} \mathrm{Na}_{0.01} \mathrm{Ca}_{0.03}\right)_{0.67}\left(\mathrm{Fe}^{3+}{ }_{1.46} \mathrm{Al}_{0.03} \mathrm{Mg}_{0.65}\right)_{2.14}\left(\mathrm{Si}_{3.50} \mathrm{Al}_{0.50}\right)_{4} \mathrm{O}_{10}(\mathrm{OH})_{2}, \mathrm{n} \mathrm{H}_{2} \mathrm{O}$.

The average structural formula for the glauconite infillings is:

$\left(\mathrm{K}_{0.56} \mathrm{Na}_{0.01} \mathrm{Ca}_{0.04}\right)_{0.61}\left(\mathrm{Fe}^{3+}{ }_{1.35} \mathrm{Al}_{0.13} \mathrm{Mg}_{0.71}\right)_{2.19}\left(\mathrm{Si}_{3.49} \mathrm{Al}_{0.51}\right)_{4} \mathrm{O}_{10}(\mathrm{OH})_{2}, \mathrm{n} \mathrm{H}_{2} \mathrm{O}$

$\mathrm{Si}^{4+}$ content per atom in the tetrahedral site of glauconitic infillings and pellets is similar.

The total iron content per formula unit is higher in pellets than infillings. The total $\mathrm{Al}^{3+}$ per formula unit is higher in infillings (av. 0.64) than in pellets (av. 0.53). $\mathrm{K}^{+}$content per formula unit in pellets is higher than in that of infillings. The tetrahedral charge of the glauconite samples of the Maniyara Fort Formation varies from 0.44 to 0.61 (av. 0.50), whereas octahedral charge varies from 0.40 to 0.53 (av. 0.45). All the data have higher than $0.2 \mathrm{Al}$ atoms per formula unit in the tetrahedral site. The total octahedral $\mathrm{R}^{3+}$ in the studied samples varies from 1.46 to 1.57 atoms (av. 1.5 atoms) per formula unit and thereby complies with glauconite composition prescribed by AIPEA (Bailey, 1980). Glauconite, Fe-illite and Fe-Al smectites form contiguous compositional domains and therefore it is difficult to distinguish these minerals based on major element composition. Meunier and El Albani (2007) proposed a useful plot to distinguish these minerals based on $4 \mathrm{M}^{+} / \mathrm{Si}$ vs. $\mathrm{Fe} / \mathrm{Sum}$ of octahedral cations coordinates. $4 \mathrm{M}$ corresponds to interlayer charge $(\mathrm{Na}+\mathrm{K}+2 \mathrm{Ca})$ multiplied by 4 . $\mathrm{Fe} / \mathrm{Sum}$ of octahedral cations and $4 \mathrm{M}^{+} / \mathrm{Si}$ ratio of most of the data exceed 0.6. All data plot inside the compositional field of glauconite according to this scheme (Figure 7).

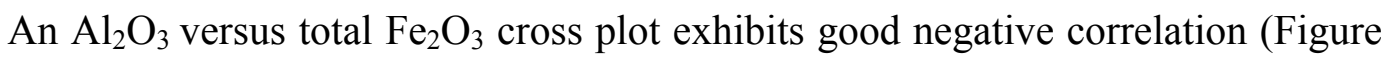
$\left.8 \mathrm{~A}, \mathrm{R}^{2}=0.69\right) . \mathrm{Al}^{3+}-\mathrm{Fe}^{3+}$ substitution in glauconite crystal structures has been noted in previous studies (Odin and Matter, 1981; Ireland et al., 1983; Velde, 1985; Dasgupta et al., 1990; Lee et al., 2002; Amorosi et al., 2007; Banerjee et al., 2008). The $\mathrm{K}_{2} \mathrm{O}$ and total $\mathrm{Fe}_{2} \mathrm{O}_{3}$ content of all glauconites exhibit a moderate correlation $\left(\mathrm{R}^{2}=0.47\right.$, Figure 8B). Glauconite pellets and infillings form separate clusters in the $\mathrm{K}_{2} \mathrm{O}$ versus total $\mathrm{Fe}_{2} \mathrm{O}_{3}$ cross plot, occurring at the two ends of the correlation line. Glauconite pellets are 
invariably richer in $\mathrm{K}_{2} \mathrm{O}$ and total $\mathrm{Fe}_{2} \mathrm{O}_{3}$ than the glauconite infillings. Odin and Matter (1981) did not observe any correlation between interlayer cations and octahedral iron, but a similar positive correlation between $\mathrm{K}_{2} \mathrm{O}$ and total $\mathrm{Fe}_{2} \mathrm{O}_{3}$ is reported in the literature (Meunier, 2003; El Albani et al., 2005; Amorosi et al., 2007). $\mathrm{A} \mathrm{K}^{+}$versus $\mathrm{Mg}^{2+}$ cross plot for all samples (Figure $8 C$ ) exhibits a negative trend $\left(R^{2}=0.51\right.$ ) that indicates release of $\mathrm{Mg}$ from the substrate as the glauconite matured. Glauconite infillings are invariably richer in $\mathrm{Mg}$ compared to the glauconite pellets. The $\mathrm{K}^{+}$versus $\mathrm{Al}^{3+}$ cross plot exhibits good negative correlation $\left(\mathrm{R}^{2}=0.66\right.$, Figure $\left.8 \mathrm{D}\right)$ and mimics $\mathrm{Al}-\mathrm{Fe}$ substitution, suggesting addition of $\mathrm{K}^{+}$in glauconite structure at the expense of $\mathrm{Al}^{3+}$.

\subsection{Trace elements and REE chemistry (glauconite pellets)}

Trace element and REE analyses were carried out on glauconite pellets. Glauconite infillings were avoided because of the difficulty in maintaining the chemical purity of the samples. Three samples from the upper green shale unit (see Figure 2) were analyzed for this purpose. These three samples are referred to as lower, middle and upper respectively in the following discussion (Table 3). Concentrations of $\mathrm{Cr}, \mathrm{Ni}, \mathrm{Co}, \mathrm{Sc}, \mathrm{V}, \mathrm{Cu}, \mathrm{Zn}, \mathrm{Ba}$, $\mathrm{Sr}, \mathrm{Zr}, \mathrm{Y}, \mathrm{La}, \mathrm{Ce}, \mathrm{Nd}, \mathrm{Sm}, \mathrm{Eu}, \mathrm{Gd}, \mathrm{Dy}, \mathrm{Yb}$ were measured. Each sample was separated into two separate fractions, heavy and light. Sampling positions, density of pellets and minimum, maximum and average concentrations of trace elements and REE are provided in Table 3. The average concentrations of trace elements and REEs in glauconite pellets are comparable to those reported from deep marine environments (e.g. Jarrar et al., 2000). The correlation matrix for the chemical data is presented in Table 4. Most of the major elements exhibit poor correlation with trace elements and REE. Cr, Ni, V and $\mathrm{Zn}$ exhibit significant positive correlations with most other trace elements and REE. This correlation is most pronounced in the case of $\mathrm{Cr}$ and $\mathrm{Ni}$. $\mathrm{V}$ and $\mathrm{Zn}$ are positively correlated with all other trace elements and REE and Zr exhibits good positive correlation with $\mathrm{Eu}, \mathrm{Dy}$ and $\mathrm{Yb}$.

The lack of significant relationships between the trace/REE and major elements suggest that the former may not be structural components of the glauconite pellets. The trace element/REE concentrations may be inherited from the substrates or adsorbed later 
on the surface of the glauconite pellets (cf. Jarrar et al., 2000). The very low values of Sm and $\mathrm{Y}$ are possibly related to the K-poor substrates. Concentrations of $\sum$ REE in the studied glauconites do not exhibit significant variation (min. 103 ppm, max. 359 ppm and av. 204 ppm). Concentrations of both $\sum$ LREE and $\sum$ HREE fractions are higher in heavier than in lighter glauconites.

The concentration of Ce offers a potential tool for deducing palaeoredox conditions. The Ce anomaly was calculated from the formulae: $\mathrm{Ce}_{\text {anom }}=\log \left[3 \mathrm{Ce}_{\mathrm{n}} /\left(2 \mathrm{La}_{\mathrm{n}}+\mathrm{Nd}_{\mathrm{n}}\right)\right]$ (Wright et al., 1987). Ce anomaly values of the samples suggest a slightly anoxic condition in the depositional substrate (Elderfield and Pagett, 1986; Wright et al., 1987). The oxic-anoxic line in Figure 9 is drawn at $-0.1 \mathrm{Ce}$ anomaly value (cf. Wright et al., 1987). Nd concentrations of the samples suggest slow to moderate sedimentation accumulation rates (cf. Elderfield et al., 1981), although the presence of highly evolved authigenic glauconite generally implies a slow rate of sedimentation (Odin and Matter, 1981).

The chondrite-normalized REE patterns for the Maniyara Fort Formation samples are characterized by weak to moderate LREE/HREE fractionation (9.6 to 16.2) and a weak negative Eu anomaly $\left(\mathrm{Eu} / \mathrm{Eu}^{*} \sim 0.32-0.41\right)$ (Table 3$)$. The weak Eu anomaly is probably inherited from a substrate where concentration of Eu was originally low with respect to other REEs and may not be related to glauconite genesis (Bau and Möller, 1992). The REE abundances are normalized to the North American Shale Composite (NASC; Gromet et al., 1984) and the plot exhibits a hat-shaped (convex upward) pattern (La to $\mathrm{Yb}$ ); a moderate depletion of HREE, less pronounced depletion of LREE and a concentration peak around Sc (Figure 10). The hat-shaped REE pattern has been reported from other authigenic minerals of marine origin (Hoyle et al., 1984; Grandjean-Lécuyer et al., 1993; Sturesson, 1995).

\section{DISCUSSION}

Although Modern glauconites are reported exclusively from sea floor deeper than $50 \mathrm{~m}$ (Porrenga, 1967; Odin and Matter, 1981; Amorosi, 2003), their ancient counterpart had apparently originated under wide ranging depositional conditions, such as, hypersaline lagoon (El Albani et al., 2005), shallow shelf and tidal flat (Dasgupta et al., 1990; 
Huggett and Gale, 1997; Chafetz and Reid, 2000), lake and palaeosols (Huggett and Cuadros, 2010). The present finding of authigenic glauconites from the lagoonal Maniyara Fort Formation lend support to the notion that the mineral does form beyond the restriction of mid-shelf and deeper marine environment (see detailed discussion in Chafetz and Reid, 2000). Our study also suggests that glauconite formation was most favoured around $20 \mathrm{~m}$ depth in the lagoon and was least favoured at the marginal part of the same lagoon.

The origin of glauconites is explained by two popular hypotheses; 'layer lattice theory' proposed by Burst (1958a, b) and Hower (1961), and 'verdissement of grains' proposed by Odin and Matter (1981). The former theory envisages incorporation of iron and potassium simultaneously into the lattice of clay minerals like high alumina smectite, illite or degraded mica. The model is particularly useful for glauconite formation involving 2:1 clay minerals. The 'verdissement of grains' model proposed by Odin and Matter (1981), on the other hand, is applicable to a wide variety of substrates including bioclasts, faecal pellets and minerals/rock fragments. In this model, glauconite precipitation commences within the micro-pores of the substrate and the initial precipitates are compositionally similar to glauconitic smectite. During progressive maturation glauconitic smectite evolves into glauconitic mica by the incorporation of potassium. The origin of glauconite is envisaged as a process of dissolution-precipitation and later maturation.

The microstructural and chemical characteristics of the Maniyara Fort Formation glauconites allow an evaluation of the two hypotheses as far as their applicability in the present situation is concerned. Both varieties of glauconite recognized within the Maniyara Fort Formation exhibit a good correlation between $\mathrm{Fe}$ and $\mathrm{K}$ (Figure 8B) supporting the layer lattice theory. However, the less mature glauconite infillings are rich in $\mathrm{K}_{2} \mathrm{O}$ and total $\mathrm{Fe}_{2} \mathrm{O}_{3}$ (5.6\% and $26.1 \%$ respectively), which is not fully consistent with the layer lattice model. Glauconite pellets also have at least $6.1 \mathrm{wt} \% \mathrm{~K}_{2} \mathrm{O}$ and $25.6 \mathrm{wt} \%$ total $\mathrm{Fe}_{2} \mathrm{O}_{3}$, which is also not consistent with the model of their derivation from 2:1 clay minerals. The preservation of delicate internal structures of foraminifers rules out dissolution of calcitic tests. The tiny chambers of the foraminifers could not have allowed 
detrital clay in the pore spaces, although seawater might have percolated through them. Authigenic precipitation of K-poor glauconite inside the foraminiferal chambers and its subsequent maturation to glauconite infillings is considered more likely. Maturation of both glauconite infillings and pellets took place apparently by simultaneous addition of $\mathrm{Fe}$ in the octahedral sites and fixation of $\mathrm{K}$ in the interlayer sites; $\mathrm{Al}, \mathrm{Mg}$ and $\mathrm{Ca}$ were released concomitantly from the substrate. It follows, that a model combining initial authigenic precipitation of K-poor glauconite, followed by incorporation of both $\mathrm{Fe}$ and $\mathrm{K}$ during later stages of maturation, may explain the formation of the Maniyara Fort glauconites. The $\mathrm{Mg}$ content of the glauconites is on the higher side and is possibly related to the presence of Mg-rich smectite clays, traces of which are found in the XRD peaks.

The maturation of glauconite infillings was aborted at an intermediate stage, as the entry to the foraminiferal chambers was closed. Limited circulation of seawater within the isolated constricted pores could be the prime reason for the restricted supply of the cations necessary for glauconite maturation. Alkaline conditions were not conducive for the dissolution of foraminiferal tests, so that glauconite pellets could not form. The glauconite pellets, on the other hand, represent an advanced stage of glauconite maturation as the faecal pellets possibly inherited the necessary cations and anions required for glauconite formation and maturation on the sediment water interface (Chafetz and Reid, 2000 and references therein); besides, their higher porosity rendered the cation supply unhindered.

The formation of glauconite is governed by the availability of iron and potassium. Iron in Maniyara Fort glauconites is obviously derived from the substrate, as seawater is depleted in iron. We envisage that the decomposition of organic matter associated with faecal pellets and foraminiferal chambers, formed sub-oxic micro-environments conducive for dissolution of iron. The presence of abundant pyrite in green shale and the negative cerium anomaly of glauconite pellets further corroborate this contention. Seawater had an appreciable amount of potassium and it was easily made available to the authigenically formed glauconite. As the glauconite matured, iron and potassium were added to the glauconite structure, at the expense of $\mathrm{Al}, \mathrm{Ca}$ and $\mathrm{Mg}$. The nature of the substrate thus primarily controlled the maturation process of glauconites and the products 
were contrasting at the same stratigraphic level. Substrate size as well as its composition favoured pellets to mature at a faster rate than the infillings. Odin and Matter (1981) emphasize the importance of low sediment accumulation rates, so that the substrate remains exposed to the open marine environment for a sufficiently long time. $\mathrm{Nd}$ concentrations of glauconite pellets in the Maniyara Fort Formation, however, suggest low to moderate sediment accumulation rate (Figure 9).

The physical and chemical conditions existing in a depositional system are likely to have a strong influence on the mineralogical and the chemical characteristics of $\mathrm{Fe}$ bearing clay minerals; Fe-illite is favoured in hypersaline lagoonal environments, while open marine conditions favour glauconite (Kosovskaya and Drits, 1970; Berg-Madsen, 1983; El Albani et al., 2005; Meunier and El Albani, 2007). Oxic conditions in a depositional setting characterized by considerable fresh water input strongly reduces the mobility of Fe ions and consequently the glauconite formed therein becomes depleted in $\mathrm{Fe}$; oxic conditions in a shallow marine setting may further decrease $\mathrm{K}^{+}$ion activity resulting in K-depleted and Al-rich glauconites (Berg-Madsen, 1983). Recently, Amorosi et al. (2007) presented bulk major element composition of Cretaceous to Pliocene deep marine glauconites from 25 western European localities covering the whole range of maturity. The $\mathrm{Fe}_{2} \mathrm{O}_{3}$ content of these glauconites varies from 22 to $26 \%$ while $\mathrm{K}_{2} \mathrm{O}$ ranges from 6 to $8.5 \%$. The lagoonal glauconites of the Maniyara Fort Formation bear close chemical similarity with these deep marine glauconites in terms of major element concentrations, as well as in X-ray diffractometrical parameters.

In the Palaeogene succession of western Kutch, slightly evolved to evolved types of glauconites also occur in stratigraphic intervals other than the Maniyara Fort Formation, such as the Naredi Formation and Harudi Formation (Chattoraj et al., 2009; Chattoraj, 2011). The Harudi Formation glauconites formed in a mid-shelf setting, and the Naredi glauconites in a lagoonal condition. Mineralogical and chemical characteristics of these Palaeogene glauconites of Kutch are broadly similar, with an av. total $\mathrm{Fe}_{2} \mathrm{O}_{3}$ content of around 25.5\% (Chattoraj, 2011). However, the Maniyara Fort Formation glauconites are even more mature, having a high $\mathrm{K}_{2} \mathrm{O}$ content (av. $4.7 \% \mathrm{~K}_{2} \mathrm{O}$ for Naredi glauconite, av. $5.1 \% \mathrm{~K}_{2} \mathrm{O}$ for Harudi glauconite against $6.2 \% \mathrm{~K}_{2} \mathrm{O}$ for Maniyara Fort glauconites). The Maniyara Fort glauconites are not associated with evaporites, as is the case for most of 
the previously reported shallow and marginal marine glauconites; the lower Fe content in the latter possibly is due to the fact that sub-oxic conditions necessary for Fe-enrichment did not last long in their depositional environments. In contrast, possibly a greater supply of organic matter prolonged the sub-oxic conditions in the Maniyara lagoon, enabling the glauconites to acquire the chemical properties similar to those of deep marine glauconites. Similar high total $\mathrm{Fe}_{2} \mathrm{O}_{3}(20-29 \%)$ and $\mathrm{K}_{2} \mathrm{O}$ (av. 6.5\%) contents in glauconite are also available, exceptionally, on a shallow shelf, such as in the Holocene, on an open continental shelf off the Yellow Sea (20 - 80 m depth; Lim et al., 2000; Lee et al., 2002).

\section{CONCLUSIONS}

The present paper firmly establishes the lagoonal origin of the fossiliferous limestone and shale comprising the Oligocene Maniyara Fort Formation. Mineralogical and geochemical data for the two varieties of glauconites (pellets and infillings) highlight some of the key aspects of the origin and maturation of glauconite which are listed below.

a) Mineralogical and chemical characteristics of the lagoonal glauconites of the Maniyara Fort Formation are broadly similar to those formed in a deep marine environment.

b) Both varieties of glauconite represent authigenic precipitation of K-poor glauconite followed by maturation through incorporation of $\mathrm{K}$ and $\mathrm{Fe}$ in the glauconite structure and concomitant release of calcium, magnesium and aluminum.

c) The glauconite infillings represent stunted maturation, because the supply of relevant cations and anions within the tiny pore chambers was hindered. Glauconite formation took place in an overall alkaline pore water condition and foraminiferal tests did not dissolve. As a consequence, the foraminiferal tests could not form glauconite pellets.

d) FWHM and d(001) proved to be equally useful parameters for assessing glauconite maturity. X-ray diffractometrical parameters, as well as $\mathrm{K}_{2} \mathrm{O}$ and $\mathrm{Fe}_{2} \mathrm{O}_{3}$ values suggest that in the studied Maniyara Fort Formation the glauconite infillings are less mature than the glauconite pellets. 
e) Trace element and REE concentrations of the glauconites are not affected during the maturation process, and concentrations of these elements are related either to the original depositional substrate or later absorption into the glauconite structure.

f) Ce-anomaly data suggest glauconite formation occurred in sub-oxic conditions, just above the oxic-anoxic boundary. The occurrence of authigenic pyrite further corroborates the oxygen depletion. Abundant organic matter in faecal pellets and within foraminiferal chambers possibly created confined, sub-oxic micro-environments conducive for glauconite formation.

g) A hat-shaped NASC-normalized REE pattern further confirms the authigenic origin of glauconites.

\section{ACKNOWLEDGEMENTS}

The authors are thankful to the Department of Science and Technology, Government of India for financial support (grant no. AR/S4/ES-281/2007 dt.28.1.2008). SB, SLC, PKS and US acknowledge infrastructural support provided by the Indian Institute of Technology Bombay. The authors thank E.V.S.S.K. Babu, NGRI, Hyderabad for the EPMA results. SDG acknowledges support from the J.C. Bose Fellowship programme of the Department of Science and Technology, Government of India. The authors are thankful to the anonymous reviewers and handling editor Alastair Ruffell for constructive criticisms and careful editing of the earlier versions of the manuscript. 


\section{REFERENCES}

Amorosi, A. 1997. Detecting compositional, spatial, and temporal attributes of glaucony: a tool for provenance research. Sedimentary Geology 109, 135-153.

Amorosi, A. 2003. Glaucony and verdine. In: Encyclopedia of Sediments and Sedimentary Rocks, Middleton, G.V. (ed.). Kluwer Academic Publishers: Dordrecht, 331-333.

Amorosi, A., Sammartino, I., Tateo, F. 2007. Evolution patterns of glaucony maturity: A mineralogical and geochemical approach. Deep-Sea Research Part II: Topical Studies in Oceanography 54, 1364-1374.

Bailey, S.W. 1980. Summary of recommendations of AIPEA nomenclature committee on clay minerals. Clays and Clay Minerals 28, 73-78.

Bandyopadhyay, P.C. 2007. Interpretation of authigenic vs. allogenic green peloids of ferric clay in the Proterozoic Penganga Group, southern India. Clay Minerals 42, $471-485$.

Banerjee, S., Jeevankumar, S., Eriksson, P.G. 2008. Mg-rich ferric illite in marine transgressive and highstand systems tracts: examples from the Paleoproterozoic Semri Group, central India. Precambrian Research 162, 212-226.

Bau, M., Möller, P. 1992. Rare earth element fractionation in metamorphogenic hydrothermal calcite, magnesite and siderite. Mineralogy and Petrology 45, $231-246$. 
Berg-Madsen, V. 1983. High-alumina glaucony from the Middle Cambrian of Öland and Bornholm, southern Baltoscandia. Journal of Sedimentary Petrology 53, 875-893.

Birch, G.F., Willis, J.P., Rickard, R.S. 1976. An electron microprobe study of glauconites from the continental margin off the west coast of South Africa. Marine Geology 22, 271-283.

Biswas, S.K. 1992. Tertiary stratigraphy of Kutch. Journal of the Palaeontological Society of India 37, 1-29.

Biswas, S.K., Raju, D.S.N. 1973. The rock stratigraphic classification of the Tertiary sediments of Kutch. Oil and Natural Gas Commission of India Bulletin 10, $37-$ 46.

Biswas, S.K., Deshpande, S.V. 1983. Geology and hydrocarbon prospects of Kutch, Saurashtra and Narmada basins. Petroleum Asia Journal 6, 111-126.

Bjerkli, K., Östmo-Saeter, J.S. 1973. Formation of glauconite in foraminiferal shells on the continental shelf off Norway. Marine Geology 14, 169-178.

Burst, J.F. 1958a. "Glauconite" pellets: Their mineral nature and applications to stratigraphic interpretations. Bulletin of the American Association of Petroleum Geologists 42, 310-327.

Burst, J.F. 1958b. Mineral heterogeneity in "glauconite" pellets. American Mineralogist 43, 481-497.

Chafetz, H.S. 1979. Petrology of carbonate nodules from a carbonate tidal inlet accumulation, central Texas. Journal of Sedimentary Petrology 49, 215-222.

Chafetz, H.S., Reid, A. 2000. Syndepositional shallow water precipitation of glauconitic minerals. Sedimentary Geology 136, 29-42. 
Chattoraj, S.L. 2011. Glauconite formation in stratigraphic framework of Palaeogene succession in Kutch. Unpublished Ph.D. Thesis, Indian institute of Technology Bombay, 241.

Chattoraj, S.L., Banerjee, S., Saraswati, P.K. 2009. Glauconites from the Late Palaeocene-Early Eocene Naredi Formation, western Kutch and their genetic implications. Journal of the Geological Society of India 73, 567-574.

Cudzil, M.R., Dreise, S. 1987. Fluvial, tidal and storm sedimentation in the Chilhowee Group (Lower Cambrian), northeastern Tennessee, U.S.A. Sedimentology 34, 861883.

Dasgupta, S., Cahudhuri, A.K., Fukuoka, M. 1990. Compositional characteristics of glauconitic alterations of K-feldspar from India and their implications. Journal of Sedimentary Petrology 60, 277-281.

Ehlmann, A.J., Hulings, N.C., Glover, E.D. 1963. Stages of glauconite formation in modern foraminiferal sediments. Journal of Sedimentary Research 33, 87-96.

El Albani, A., Meunier, A., Fursich, F. 2005. Unusual occurrence of glauconite in a shallow marine lagoonal environment. Terra Nova 17, 537-544.

Elderfield, H., Pagett, R. 1986. REE in ichthyoliths: Variation with redox conditions and depositional environment. Science of the Total Environment 49, 175-197.

Elderfield, H., Hawkesworth, C.J., Greaves, M.J., Calvert, S.E. 1981. Rare earth element geochemistry of oceanic ferromanganese nodules and associated sediments. Geochimica et Cosmochimica Acta 45, 513-528.

Fleet, A.J., Buckley, H.A., Johnson, L.R. 1980. The rare earth element geochemistry of glauconites and celadonites. Journal Geological Society, London 137, 683-688. 
Ghose, B.K. 1982. Oligocene reef of Kutch and its oil potentiality. Indian Journal of Earth Sciences 9, 6-10.

Giresse, P., Wiewióra, A. 2001. Stratigraphic condensed deposition and diagenetic evolution of green clay minerals in deep water sediments on the Ivory Coast-Ghana Ridge. Marine Geology 179, 51-70.

Gonzalez, R., Dias, J.M.A., Lobo, F., Mendes, I. 2004. Sedimentological and paleoenvironmental characterisation of transgressive sediments on the Guadiana Shelf (Northern Gulf of Cadiz, SW Iberia). Quaternary International 120, $133-144$

Grandjean-Lécuyer, P., Feist, R., Albarède, F. 1993. Rare earth elements in old biogenic apatites. Geochimica et Cosmochimica Acta 57, 2507-2514.

Gromet, L.P., Dymek, R.F., Haskin, L.A., Korotev, R.L. 1984. The "North American Shale Composite": Its compilation, major and trace element characteristics. Geochimica et Cosmochimica Acta 48, 2469-2482.

Hower, J. 1961. Some factors concerning the nature and origin of glauconite. American Mineralogist 46, 313-334.

Hoyle, J., Elderfield, H., Gledhill, A., Greaves, M. 1984. The behaviour of rare earth elements during mixing of river and sea waters. Geochimica et Cosmochimica Acta 48, 147-149.

Huggett, J.M., Gale, A.S. 1997. Petrology and paleoenvironmental significance of glaucony in the Eocene succession at Whitecliff Bay, Hampshire Basin, UK. Journal of the Geological Society of London 154, 897-912. 
Huggett, J.M., Cuadros, J. 2010. Glauconite formation in lacustrine/palaeosol sediments, Isle of Wight (Hampshire Basin), UK. Clay Minerals 45, 35-49.

Ireland, B.J., Curtis, C.D., Whiteman, J.A. 1983. Compositional variation within some glauconites and illites and implications for their stability and origins. Sedimentology 30, 769-786.

Jackson, M.L. 1979. Soil Chemical Analysis -Advanced Course. 2nd Edition, University of Wisconsin, Madison, 895.

Jarrar, G., Amireh, B., Zachmann, D. 2000. The major, trace and rare earth element geochemistry of glauconites from the early Cretaceous Kurnub Group of Jordan. Geochemical Journal 34, 207-222.

Kelly, J.C., Webb, J.A. 1999. The genesis of glaucony in the Oligo-Miocene Torquay Group, southeastern Australia: petrographic and geochemical evidence. Sedimentary Geology 125, 99-114.

Kim, Y., Lee, Y.I. 2000. Ironstones and green marine clays in the Dongjeom formation (Early Ordovician) of Korea. Sedimentary Geology 130, 65-80.

Kohler, E.E., Köster, H.M. 1976. Zur mineralogie, kristallchemie und geochemie kretazisches glauconite. Clay Minerals 11, 273-302.

Kosovskaya, A.G., Drits, V.A. 1970. The variability of micaceous minerals in sedimentary rocks. Sedimentology 15, 83-101.

Kumar, A., Saraswati, P.K. 1997. Response of larger foraminifera to mixed carbonatesiliciclastic environment: an example from the Oligocene-Miocene sequence of Kutch, India. Palaeogeography, Palaeoclimatology, Palaeoecology 136, 53-65.

Kumar, P., Saraswati, P.K., Banerjee, S., 2009. Early Miocene shell concentration in the mixed carbonate-siliciclastic system of Kutch and their distribution in 
sequence stratigraphic framework. Journal of the Geological Society of India 74, $432-444$.

Lee, C.H., Choi, S., Suh, M. 2002. High iron glaucony from the continental shelf of the Yellow Sea off the southwestern Korean Peninsula. Journal of Asian Earth Sciences 20, 507-515.

Lim, D.I., Park, Y.A., Choi, J.Y., Cho, J.W., Khim, B.K. 2000. Glauconite grains in continental shelf sediments around the Korean Peninsula and their depositional conditions. Geo-Marine Letters 20, 80-86.

McRae, S.G. 1972. Glauconite. Earth-Science Reviews 8, 397-440.

Meunier, A. 2003. Clays. Springer-Verlag: New York, 472.

Meunier, A., El Albani, A. 2007. The glauconite-Fe-illite-Fe-smectite problem: a critical review. Terra Nova 19, 95-104

Nishimura, T. 1994. Occurrence and properties of glauconite in Miocene biosiliceous sediments of the Noto Peninsula, Hokurikku District, Japan. Proceedings 29th International Geological Congress, Part C, 75-87.

Odin, G.S., Matter, A. 1981. De glauconiarum origine. Sedimentology 28, 611-641.

Odin, G.S., Fullagar, P.D. 1988. Geological significance of the glaucony facies. In: Green Marine Clays, Odin, G.S. (ed.). Elsevier: Amsterdam, 295-332.

Pande, K. 2002. Age and duration of the Deccan Traps, India: A review of radiometric and paleomagnetic constraints. Proceedings of the Indian Academy of Sciences (Earth and Planetary Sciences) 111, 115-123.

Pasquini, C., Lualdi, A., Vercesi, P. 2004. Depositional dynamics of glaucony-rich deposits in the Lower Cretaceous of Nice arc, Southeast France. Cretaceous Research 25, 179-189. 
Porrenga, D.H. 1967. Glauconite and chamosite as depth indicators in the marine environment. Marine Geology 5, 495-501.

Raju, D.S.N. 1974. Study on Indian Miogypsinidae. Utrecht Micropalaeontological Bulletin 9, 1-148.

Rao, V.P., Lamboy, M., Dupeuble, P.A. 1993. Verdine and other associated authigenic (glaucony, phosphate) facies from the sediments of the southwestern continental margin of India. Marine Geology 111, 133-158.

Saraswati, P.K., 1995. Biometry of early Oligocene Lepidocyclina from Kutch, India. Marine Micropaleontology 26, 303-311.

Saraswati, P.K., Banerji, R.K. 1984. Post-Trappean sedimentation history of the north western Kutch. Proceedings Indian Colloquium Micropalaeontology and Stratigraphy 10, 377-390.

Saraswati, P.K., Patra, P.K., Banerji, R.K. 2000. Biometric study of some Eocene Nummulites and Assilina from Kutch and Jaisalmer, India. Journal of the Palaeontological Society of India 45, 91-122.

Singh, I.B. 1978. Microfacies, petrography and mineralogy of the Tertiary Rock of Guar Nala near Narayan Sarovar, Kutch, India, and their palaeoecological significance. Journal of the Palaeontological Society of India 21-22, 78-95.

Stille, P., Clauer, N. 1994. The process of glauconitization: chemical and isotopic evidence. Contribution to mineralogy and Petrology 117, 253-262.

Sturesson, U. 1995. Llanvirnian (Ord) iron ooids in Baltoscandia: Element mobility, REE distribution patterns and origin of REE. Chemical Geology 125, 45-60.

Takahashi, J.I. 1939. Synopsis of glauconitization. In: Recent Marine Sediments. A symposium, Trask, P.D. (ed.). Bulletin of the American Association of Petroleum Geology 23, 502-512. 
Thompson, G.R., Hower, J. 1975. The mineralogy of glauconite. Clays and Clay Minerals 23, 289-300.

Valeton, I., Abdul-Razzak, A., Klussmann, D. 1982. Mineralogy and geochemistry of glauconite pellets from Cretaceous sediments in northwest Germany. Geologisches Jahrbuch 52, 5-93.

Van Houten, F.B., Purucker, M.E. 1984. Glauconitic peloids and chamositic ooidsfavorable factors, constraints, and problems. Earth Science Reviews 20, 211-250.

Velde, B. 1985. Clay Minerals: Developments in Sedimentology 40. Elsevier, Amsterdam, 427.

Wigley, R., Compton, J.S. 2007. Oligocene to Holocene glauconite-phosphorite grains from the Head of the Cape Canyon on the western margin of South Africa. DeepSea Research II 54, 1375-1395.

Wright, J., Schrader, H., Holser, W. 1987. Palaeoredox variation in ancient oceans recorded by rare earth elements in fossil apatite. Geochimica et Cosmochimica Acta 51, 631-644.

Zachmann, D.W. 1988. Matrix effects in the separation of rare-earth elements, scandium, and yttrium and their determination by inductively coupled plasma optical emission spectrometry. Analytical Chemistry 60, 420-427. 


\section{TABLE CAPTIONS}

Table 1. Palaeogene stratigraphy and lithological variations in western Kutch (after Biswas, 1992)

Table 2. Oxide weight percentage of glauconite grains.

Table 3. Trace and REE concentrations (in ppm) of glauconites. $\mathrm{H}$ and $\mathrm{L}$ refers to the heavy and light glauconites respectively. The chemical composition of the North American Shale Composite (NASC) is after Gromet et al. (1984). The range of chemical composition of glauconite is compiled from the literature (Kohler and Köster, 1976; Fleet et al., 1980; Odin and Matter, 1981; Valeton et al., 1982; Ireland et al., 1983; Odin and Fullagar, 1988; Nishimura, 1994; Stille and Clauer, 1994; Jarrar et al., 2000).

Table 4. The correlation matrix for the chemical data of the Maniyara Fort Formation glauconites (very poor correlation values are not presented).

\section{FIGURE CAPTIONS}

Figure 1. Geological map showing Cenozoic outcrops in western Kutch and location of the study area (modified after Biswas and Raju, 1973) (map of India within inset).

Figure 2. Facies succession of the Maniyara Fort Formation in the Kunrajpur section showing internal structures, foraminiferal assemblages, biozones and 
palaeobathymetric variation. Variation of glauconite content up through the section is presented to the right of the grain-size column. Arrows indicate sample positions for micropalaeontological investigations.

Figure 3. Outcrop photographs of the constituent facies of the Maniyara Fort Formation. (A) Small-scale cross-stratification in the limestone facies (marker length=13 cm); (B) Nummulites concentrations in the limestone facies (match-stick length $=4.5$ $\mathrm{cm}$ ); (C) Vertical section showing the palaeokarst surface at the contact between limestone and shale, as shown in Figure 2, occurring c. $2 \mathrm{~m}$ above the base of the Formation; (D) Vertical section showing red shale and green shale overlying the palaeokarst surface (length of hammer lying on the bedding surface $=35 \mathrm{~cm}$ ).

Figure 4. Photomicrographs (cross polars), (A) Cracks (marked by the white arrow) within the glauconite pellets filled with iron oxide; (B) Syntaxial overgrowth of glauconite on glauconite pellet (marked by the black arrow); (C) Glauconite overgrowth (marked by black arrow) and pyrite grain (marked by white arrow); (D) Photomicrograph showing two pyrite cubes (white arrows) under reflected light; (E, F) Photomicrographs (plane-polarized light) showing glauconite infillings within the nummulitic foraminiferal chambers (glauconitized proloculus and lateral chambers marked by white and black arrows respectively).

Figure 5: XRD diffractograms of glauconite pellets (A to C). (A) Air-dried sample exhibiting characteristic basal reflection peak (001) marked by subdued intensity and asymmetric shape; (B) The basal reflection peak becomes sharper and more symmetrical after glycolation; (C) Peaks remaining unchanged after heating, except for the diminished kaolinite peak. XRD diffractograms of glauconite infillings (D - 
F). (D) Air-dried sample exhibiting a relatively broad and asymmetrical basal reflection with subdued intensity; (E) Peak separation after glycolation, represented by a relatively symmetrical, solitary $10.2 \AA$ peak; (F) Peaks remaining unchanged after heating, except for the diminished kaolinite peak.

Figure 6. Comparison of XRD patterns of glauconite infillings (top three) and glauconite pellets (bottom four, bold) showing the relationship among the position of the firstorder basal peak (001), FWHM and $\mathrm{K}_{2} \mathrm{O} \%$. Only the glauconite peaks are presented.

Figure 7. Compositional fields of Fe-bearing clay phases in the $4 \mathrm{M}+/ \mathrm{Si}$ vs. Fe/sum of octahedral cations (plot after Meunier and El Albani, 2007) $(\mathrm{MLM}=$ mixed layer minerals. $\mathrm{M}+$ corresponds to the interlayer charge $\mathrm{Na}+\mathrm{K}+2 \mathrm{Ca}$ ).

Figure 8. Cross plots between oxides. (A) Plot of $\mathrm{Fe}_{2} \mathrm{O}_{3}$ (total) vs. $\mathrm{Al}_{2} \mathrm{O}_{3}$ for glauconite pellets and infillings showing a moderate negative correlation; (B) Plot of $\mathrm{K}_{2} \mathrm{O}$ vs. $\mathrm{Fe}_{2} \mathrm{O}_{3}$ (total) for glauconite pellets and glauconite infillings showing a moderate positive trend; (C) Plot of $\mathrm{K}^{+}$vs. $\mathrm{Mg}^{2+}$ for glauconite pellets and glauconite infillings showing a negative correlation; (D) Plot of $\mathrm{K}^{+} \mathrm{vs}^{-\mathrm{Al}^{3+}}$ for glauconite pellets and glauconite infillings showing a negative correlation.

Figure 9. Ce anomaly versus $\mathrm{Nd}$ concentrations plot; the dividing line between anoxic and oxic is after Wright et al. (1987). Note that glauconitization of faecal pellets took place in a slightly anoxic condition close to the oxic-anoxic boundary, with moderate to slow sediment accumulation.

Figure 10. NASC-normalized REE, Y and Sc plots (normalizing values after Gromet et al., 1984). 
Table 1. Palaeogene stratigraphy and lithological variations in western Kutch (after Biswas, 1992)

\begin{tabular}{|c|c|c|c|}
\hline AGE & FORMATION & MEMBER & LITHOLOGY \\
\hline \multicolumn{4}{|c|}{ Miocene $\quad$ Khari Nadi Formation } \\
\hline Late Oligocene & \multirow[b]{2}{*}{ Maniyara Fort } & Bermoti & \multirow{2}{*}{$\begin{array}{l}\text { Foraminiferal limestone, shale } \\
\text { Foraminiferal and coralline limestone, shale } \\
\text { Grey and green shale } \\
\text { Green and red shale, limestone } \\
\end{array}$} \\
\hline Early Oligocene & & $\begin{array}{l}\text { Coral Limestone } \\
\text { Lumpy Clay } \\
\text { Basal Member } \\
\end{array}$ & \\
\hline \multirow{2}{*}{$\begin{array}{l}\text { Late Eocene } \\
\text { Middle to }\end{array}$} & Fulra Limestone & & Foraminiferal limestone \\
\hline & Harudi & & $\begin{array}{l}\text { Calcareous shale, siltstone, } \\
\text { fossiliferous shale }\end{array}$ \\
\hline \multirow{3}{*}{$\begin{array}{l}\text { Early Eocene } \\
\text { Late Palaeocene to }\end{array}$} & & Ferruginous Claystone & Red shale \\
\hline & Naredi & Assilina Limestone & Limestone \\
\hline & -Unconformity. & Gypseous Shale & Red and green shale, lignite \\
\hline Early Palaeocene & Matanomadh & & $\begin{array}{l}\text { Volcaniclastics-rich shale, } \\
\text { sandstone, claystone }\end{array}$ \\
\hline \multicolumn{4}{|c|}{$\begin{array}{l}\text { Early Palaeocene } \\
\text { Late Cretaceous to }\end{array}$} \\
\hline
\end{tabular}


Table 2. Oxide weight percentage of glauconite grains

$\begin{array}{lccccccccr}\text { Sample Points } & \mathrm{SiO}_{2} & \mathrm{Al}_{2} \mathrm{O}_{3} & \mathrm{Fe}_{2} \mathrm{O}_{3}{ }^{*} & \mathrm{MgO} & \mathrm{MnO} & \mathrm{CaO} & \mathrm{K}_{2} \mathrm{O} & \mathrm{Na}_{2} \mathrm{O} & \mathrm{Total} \\ 40 / 1-\mathrm{P} & 47.65 & 6.74 & 26.48 & 6.22 & 0.02 & 0.27 & 7.10 & 0.09 & 94.57 \\ 48 / 1-\mathrm{P} & 49.19 & 6.14 & 26.27 & 5.77 & 0.00 & 0.38 & 7.04 & 0.14 & 94.93 \\ 54 / 1-\mathrm{P} & 48.27 & 5.31 & 28.01 & 5.79 & 0.01 & 0.43 & 6.69 & 0.12 & 94.63 \\ 58 / 1-\mathrm{P} & 47.71 & 6.86 & 26.47 & 6.28 & 0.04 & 0.48 & 6.73 & 0.06 & 94.63 \\ 60 / 1-\mathrm{P} & 47.97 & 6.77 & 25.56 & 6.41 & 0.01 & 0.38 & 6.57 & 0.10 & 93.77 \\ 61 / 1-\mathrm{P} & 48.09 & 5.84 & 27.05 & 6.02 & 0.01 & 0.50 & 6.73 & 0.08 & 94.32 \\ 62 / 1-\mathrm{P} & 47.78 & 5.86 & 27.13 & 6.10 & 0.01 & 0.50 & 6.88 & 0.07 & 94.33 \\ 63 / 1-\mathrm{P} & 47.88 & 5.12 & 27.30 & 5.48 & 0.00 & 0.40 & 7.20 & 0.10 & 93.48 \\ 66 / 1-\mathrm{P} & 48.66 & 5.81 & 26.86 & 6.01 & 0.00 & 0.45 & 6.77 & 0.12 & 94.68 \\ 67 / 1-\mathrm{P} & 49.67 & 6.28 & 26.38 & 5.80 & 0.03 & 0.45 & 6.91 & 0.14 & 95.66 \\ 68 / 1-\mathrm{P} & 48.89 & 6.51 & 25.95 & 6.13 & 0.00 & 0.48 & 6.85 & 0.07 & 94.88 \\ 70 / 1-\mathrm{P} & 49.21 & 5.47 & 26.96 & 5.67 & 0.00 & 0.37 & 7.02 & 0.09 & 94.79 \\ 75 / 1-\mathrm{P} & 45.52 & 6.88 & 26.99 & 6.16 & 0.07 & 0.40 & 6.37 & 0.14 & 92.53 \\ 79 / 1-\mathrm{P} & 46.59 & 7.04 & 26.20 & 6.05 & 0.00 & 0.59 & 6.06 & 0.06 & 92.59 \\ 81 / 1-\mathrm{P} & 48.19 & 6.61 & 26.19 & 6.15 & 0.00 & 0.41 & 6.70 & 0.08 & 94.33 \\ 47 / 1-\mathrm{I} & 47.47 & 8.21 & 23.44 & 7.06 & 0.08 & 0.59 & 5.63 & 0.06 & 92.54 \\ 49 / 1-\mathrm{I} & 48.28 & 6.75 & 25.55 & 6.61 & 0.01 & 0.43 & 6.43 & 0.10 & 94.16 \\ 51 / 1-\mathrm{I} & 48.50 & 7.34 & 24.29 & 6.21 & 0.00 & 0.39 & 6.30 & 0.13 & 93.16 \\ 69 / 1-\mathrm{I} & 47.53 & 7.02 & 24.74 & 6.02 & 0.02 & 0.50 & 6.11 & 0.05 & 91.99 \\ 71 / 1-\mathrm{I} & 48.14 & 6.38 & 25.34 & 6.13 & 0.03 & 0.39 & 6.40 & 0.07 & 92.88 \\ 78 / 1-\mathrm{I} & 48.74 & 8.65 & 24.04 & 7.07 & 0.00 & 0.64 & 5.73 & 0.05 & 94.92 \\ 90 / 1-\mathrm{I} & 47.86 & 7.62 & 26.09 & 6.81 & 0.07 & 0.49 & 6.00 & 0.05 & 94.99\end{array}$

P \& I: Glauconitic Pellets \& Glauconitic Infillings $\mathrm{Fe}_{2} \mathrm{O}_{3}{ }^{*}$ : Total Iron expressed as $\mathrm{Fe}_{2} \mathrm{O}_{3}$ 
Table 3. Trace and REE concentrations (in ppm) of glauconites. $\mathrm{H}$ and $\mathrm{L}$ refers to the heavy and light glauconites respectively. The chemical composition of the North American Shale Composite (NASC) is after Gromet et al. (1984). The range of chemical composition of glauconite is compiled from the literature (Kohler and Köster, 1976; Fleet et al., 1980; Odin and Matter, 1981; Valeton et al., 1982; Ireland et al., 1983; Odin and Fullagar, 1988; Nishimura, 1994; Stille and Clauer, 1994; Jarrar et al., 2000).

\begin{tabular}{|c|c|c|c|c|c|c|c|c|c|c|c|}
\hline $\begin{array}{l}\text { Serial No } \longrightarrow \\
\text { Relative Sample }\end{array}$ & $\begin{array}{c}1 \\
\text { Lower }\end{array}$ & $\begin{array}{c}2 \\
\text { Middle }\end{array}$ & $\begin{array}{c}3 \\
\text { Upper }\end{array}$ & $\begin{array}{c}4 \\
\text { Lower }\end{array}$ & $\begin{array}{c}5 \\
\text { Middle }\end{array}$ & $\begin{array}{c}6 \\
\text { Upper }\end{array}$ & Kun & $\begin{array}{l}\text { ur Glauconi } \\
\text { his Study) }\end{array}$ & & $\begin{array}{c}\text { North Amer. } \\
\text { Shale }\end{array}$ & $\begin{array}{c}\text { Glauconite } \\
\text { from }\end{array}$ \\
\hline $\begin{array}{l}\text { Density } \longrightarrow \\
\text { Element } \downarrow\end{array}$ & H & H & H & L & L & L & Maximum & Minimum & Average & Composition & Literature \\
\hline $\mathrm{Cr}$ & 357 & 198 & 148 & 271 & 146 & 135 & 357 & 146 & 220 & 124.50 & $15-386$ \\
\hline $\mathrm{Ni}$ & 102 & 95 & 87 & 112 & 88 & 88 & 112 & 87 & 96 & 58.00 & $10-176$ \\
\hline Co & 53 & 69 & 89 & 60 & 49 & 79 & 89 & 49 & 67 & 25.70 & $1-50$ \\
\hline Sc & 31 & 37 & 42 & 34 & 23 & 41 & 42 & 23 & 34 & 14.90 & 8.00 \\
\hline v & 355 & 260 & 226 & 293 & 155 & 218 & 355 & 155 & 252 & 130.00 & $90-300$ \\
\hline $\mathrm{Cu}$ & 40 & 52 & 52 & 32 & 37 & 58 & 58 & 32 & 45 & 45.00 & $0-131$ \\
\hline $\mathrm{Zn}$ & 577 & 925 & 213 & 667 & 296 & 123 & 925 & 123 & 481 & 98.00 & $0-184$ \\
\hline $\mathrm{Ba}$ & 68 & 115 & 34 & 31 & 37 & 51 & 115 & 31 & 60 & 636.00 & $0-144$ \\
\hline Sr & 31 & 54 & 21 & 26 & 30 & 104 & 104 & 21 & 49 & 142.00 & $9-116$ \\
\hline $\mathrm{Zr}$ & 168 & 170 & 141 & 161 & 95 & 171 & 171 & 95 & 146 & 200.00 & 29.00 \\
\hline $\mathrm{Y}$ & 15 & 16 & 14 & 13 & 9 & 16 & 16 & 9 & 14 & 27.00 & \\
\hline La & 58 & 33 & 21 & 50 & 21 & 22 & 58 & 21 & 36 & 31.10 & $1.05-61.3$ \\
\hline $\mathrm{Ce}$ & 186 & 85 & 47 & 157 & 58 & 49 & 186 & 47 & 102 & 66.70 & $2.52-131.1$ \\
\hline Nd & 80 & 38 & 22 & 69 & 25 & 23 & 80 & 22 & 45 & 27.40 & $1.31-68.3$ \\
\hline Sm & 14 & 7 & 4 & 12 & 5 & 5 & 14 & 4 & 8 & 5.59 & $0.27-21.4$ \\
\hline$\sum$ LREE & 339 & 163 & 94 & 287 & 109 & 99 & 339 & 94 & 190 & & \\
\hline Eu & 3 & 2 & 1 & 2 & 1 & 1 & 3 & 1 & 2 & 1.18 & $0.06-3.23$ \\
\hline Gd & 10 & 6 & 4 & 10 & 4 & 4 & 10 & 4 & 6 & 5.50 & $0.28-15.0$ \\
\hline Dy & 6 & 4 & 3 & 5 & 3 & 4 & 6 & 3 & 4 & 5.54 & 5.40 \\
\hline Yb & 2 & 2 & 1 & 1 & 1 & 2 & 2 & 1 & 1 & 3.11 & $0.16-5.97$ \\
\hline$\sum$ HREE & 21 & 13 & 9 & 19 & 8 & 10 & 21 & 8 & 14 & & \\
\hline$\sum$ LREE $/ \sum$ HREE & 16.2 & 12.3 & 10.0 & 15.5 & 13.2 & 9.6 & 16.2 & 9.6 & 12.8 & & \\
\hline$\sum$ REE & 359 & 176 & 103 & 306 & 118 & 110 & 359 & 103 & 204 & & \\
\hline $\mathrm{Eu} / \mathrm{Eu} \mathbf{u}^{*}$ & 0.32 & 0.38 & 0.42 & 0.33 & 0.35 & 0.40 & 0.42 & 0.32 & 0.37 & & \\
\hline Ce anomaly & 0.114 & 0.057 & 0.016 & 0.109 & 0.076 & 0.003 & 0.114 & 0.003 & 0.061 & & \\
\hline
\end{tabular}


Table 4. The correlation matrix for the chemical data of the Maniyara Fort glauconites (very poor correlation values are not presented)

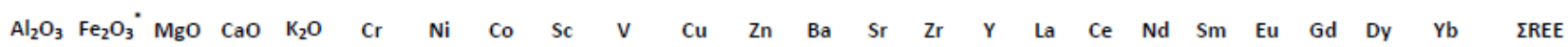
$\mathrm{Al}_{2} \mathrm{O}_{3} \quad 1.00$

$\mathrm{Fe}_{2} \mathrm{O}_{3}^{*} \quad-0.45 \quad 1.00$

$\begin{array}{lll}\text { MgO } & 0.75 & 1.00\end{array}$

$\begin{array}{llll}\mathrm{CaO} & -0.60 & -0.97 & 1.00\end{array}$

$\begin{array}{llllll}\mathrm{K}_{2} \mathrm{O} & -0.45 & -0.47 & -0.51 & 0.52 & 1.00\end{array}$

$\begin{array}{lll}\mathrm{Cr} & -0.30 & 1.00\end{array}$

$\begin{array}{llllll}\mathrm{Ni} & & & 0.65 & 1.00 & \\ \mathrm{Co} & 0.43 & -0.31 & & & 1.00\end{array}$

$\begin{array}{llllllll}\text { Sc } & 0.63 & 0.38 & -0.32 & -0.47 & 0.88 & 1.00\end{array}$

$\begin{array}{lllllllll}\mathrm{V} & & 0.46 & -0.58 & 0.84 & 0.55 & & & 1.00 \\ \mathrm{Cu} & 0.41 & & & & -0.30 & -0.47 & 0.63 & 0.56\end{array}$

Zn $\quad-0.34$

0.41

$\begin{array}{llllll}-0.30 & -0.47 & 0.63 & 0.56 & 1.00 & 1.00\end{array}$

$-0.33$

$\begin{array}{llll}0.30 & 0.42 & 0.30 & 1.00\end{array}$

$\mathrm{Sr}$

$\mathrm{Zr}$

$Y$

La

$\mathrm{Ce}$

$\mathrm{Nd}$

$\mathrm{Sm}$

Eu

Gd

Dy

Yb
EREE

(2)

$\begin{array}{llll}0.30 & & 1.00 & \\ & & 0.48 & 1.00\end{array}$

$\begin{array}{lllll}0.49 & 0.48 & -0.49 & -0.35\end{array}$

$\begin{array}{ll}0.39 & 0.52\end{array}$

$\begin{array}{lll}0.66 & -0.34 & 0.35\end{array}$

$\begin{array}{llllll}0.30 & 0.58 & 0.41 & 0.35\end{array}$

1.00

$-0.30$

$\begin{array}{llllll}0.97 & 0.78 & 0.85 & -0.32 & 0.35\end{array}$

$\begin{array}{lllllll}0.96 & 0.79 & -0.33 & 0.78 & -0.41 & 0.32\end{array}$

$\begin{array}{lllllll}0.96 & 0.80 & -0.31 & 0.79 & -0.40 & 0.32\end{array}$

$\begin{array}{llll}-0.30 & 0.97 & -0.79 & -0.30\end{array}$

$\begin{array}{lll}0.81 & 0.38 & 0.30\end{array}$

$\begin{array}{lll}0.87 & -0.31 & 0.36\end{array}$

$\begin{array}{ll}0.95 & 0.82 \\ 0.94 & 0.84\end{array}$

-0.34
-0.31

$\begin{array}{ll}0.94 & 0.84 \\ 0.90 & 0.67\end{array}$

0.41

$\begin{array}{ll}0.35 & -0.45\end{array}$

$\begin{array}{lll}0.97 & 0.80 & -0.31\end{array}$

0.34

$0.32 \quad 0.40$

$\begin{array}{lll}0.80 & -0.39 & 0.32\end{array}$

0.52

1.00

$0.88 \quad 1.00$

1.00

0.941 .00

0.990 .991 .00

$\begin{array}{llll}0.99 & 0.99 & 0.94 & 1.00\end{array}$

$\begin{array}{lllllll}0.30 & 0.99 & 0.97 & 0.98 & 0.99 & 1.00\end{array}$

$\begin{array}{llllll}0.99 & 0.99 & 0.99 & 0.99 & 0.99 & 1.00\end{array}$

$\begin{array}{lllllllll}0.47 & & 0.93 & 0.88 & 0.89 & 0.90 & 0.94 & 0.91 & 1.00\end{array}$

$\begin{array}{llllllllll}0.47 & & 0.93 & 0.88 & 0.89 & 0.90 & 0.94 & 0.91 & 1.00 & \\ 0.86 & 0.93 & & & & & & & 0.34 & 1.00\end{array}$

$\begin{array}{lllllll}0.99 & 0.99 & 0.99 & 0.99 & 0.98 & 0.99 & 0.98\end{array}$

\section{$\mathrm{Fe}_{2} \mathrm{O}_{3}{ }^{*}$ : Total Iron expressed as $\mathrm{Fe}_{2} \mathrm{O}_{3}$}




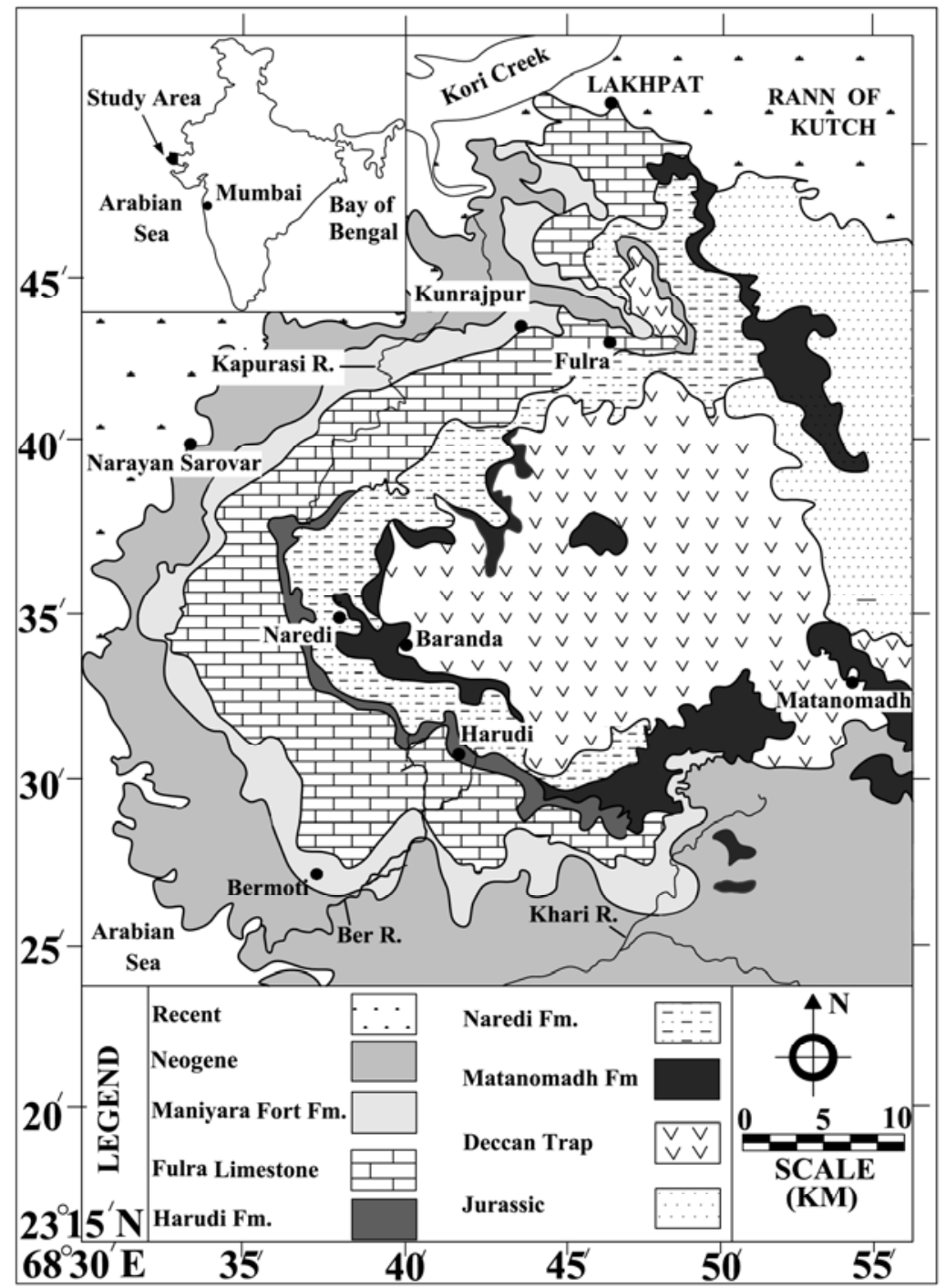

Figure 1 


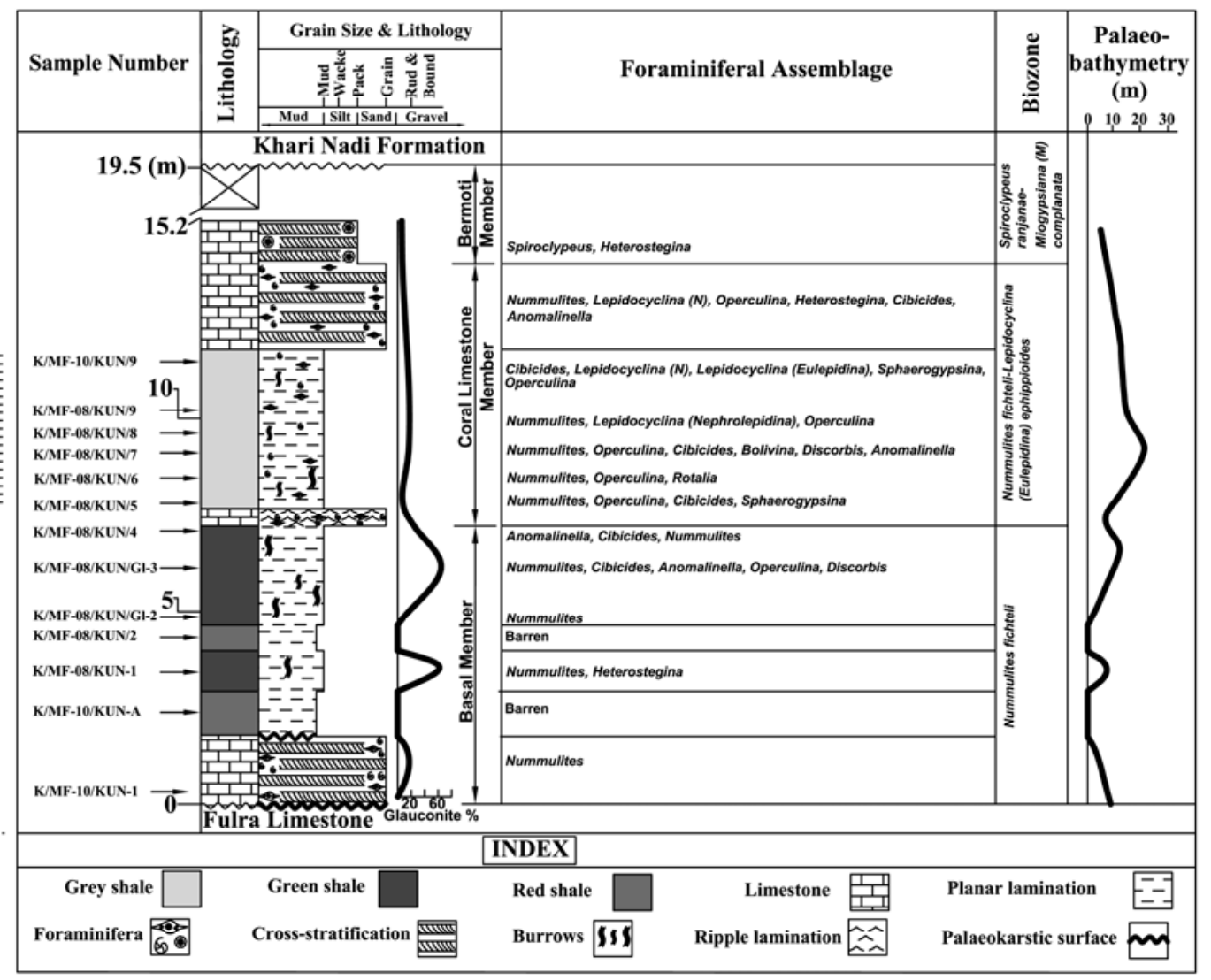

Figure 2

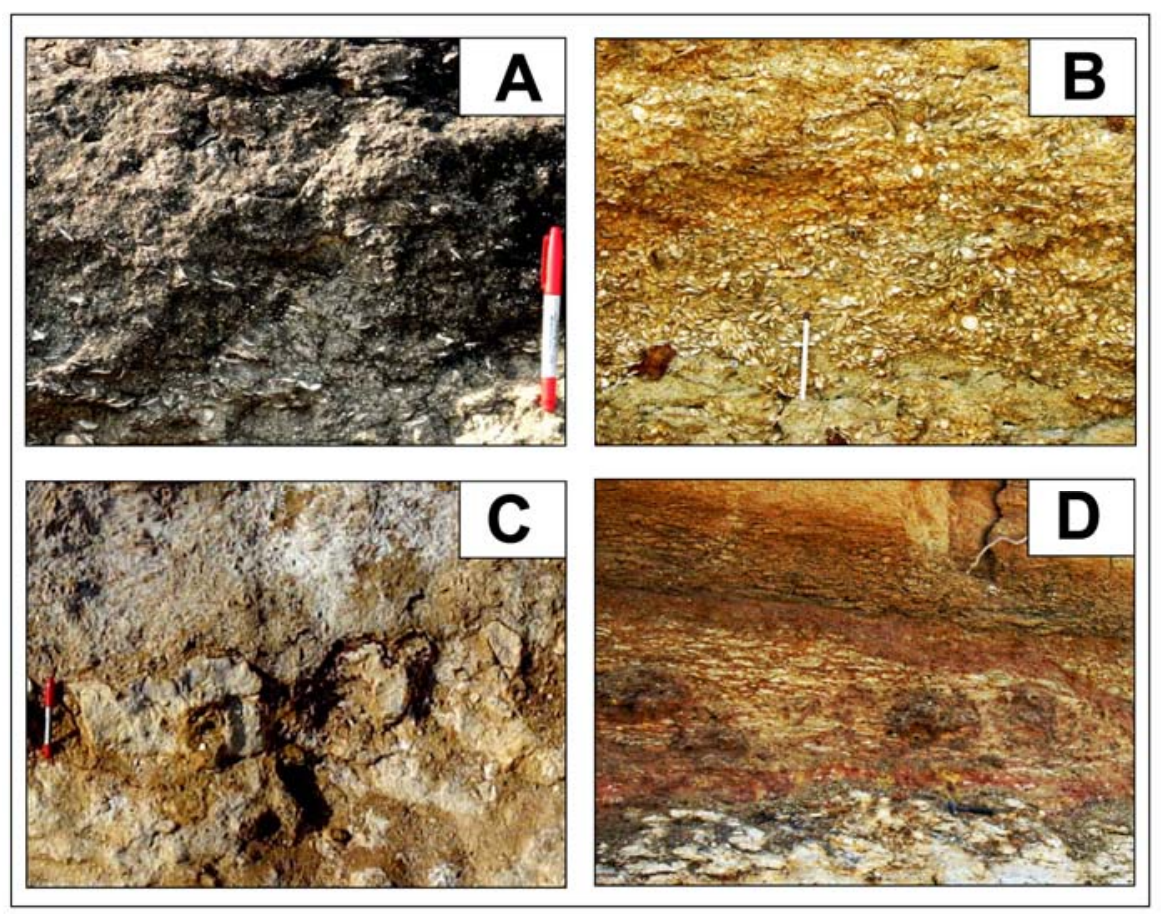

Figure 3 


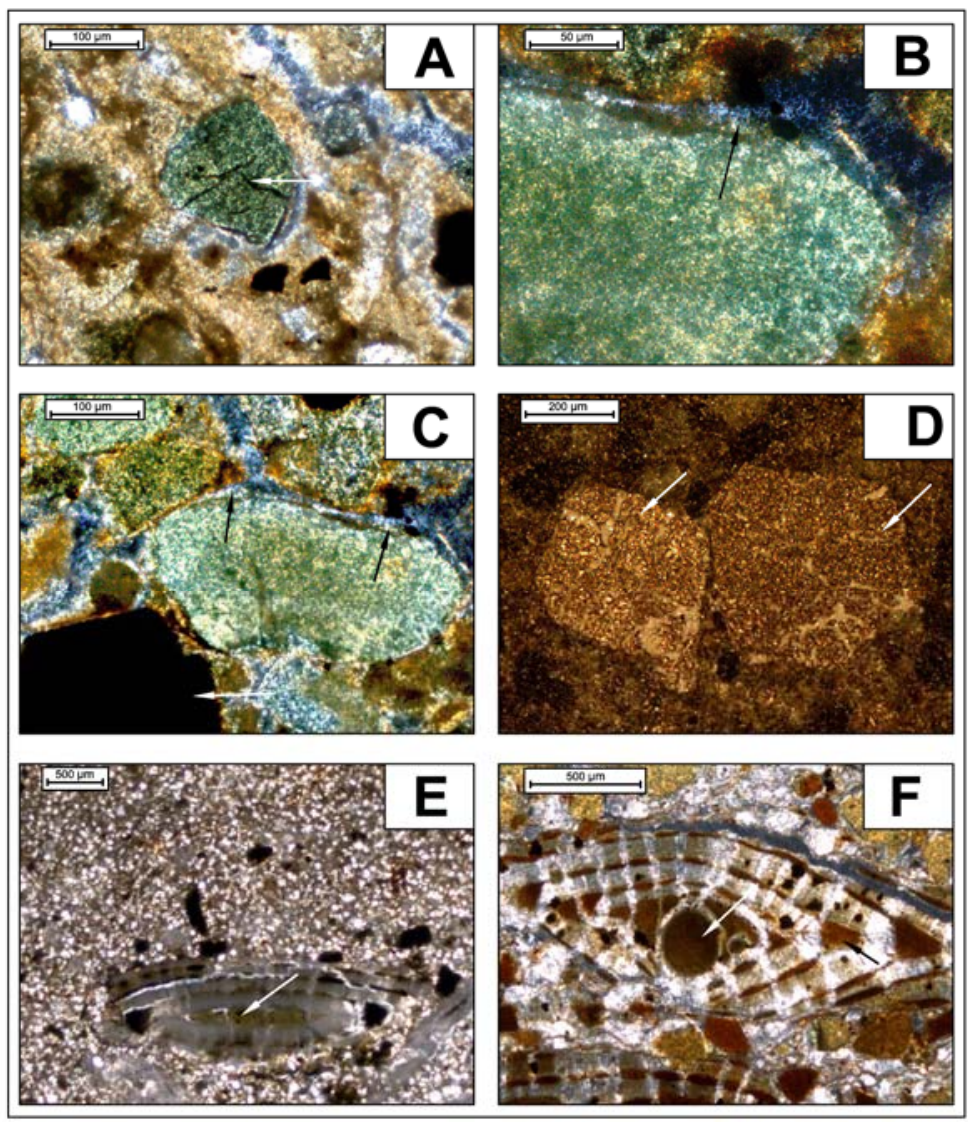

Figure 4 


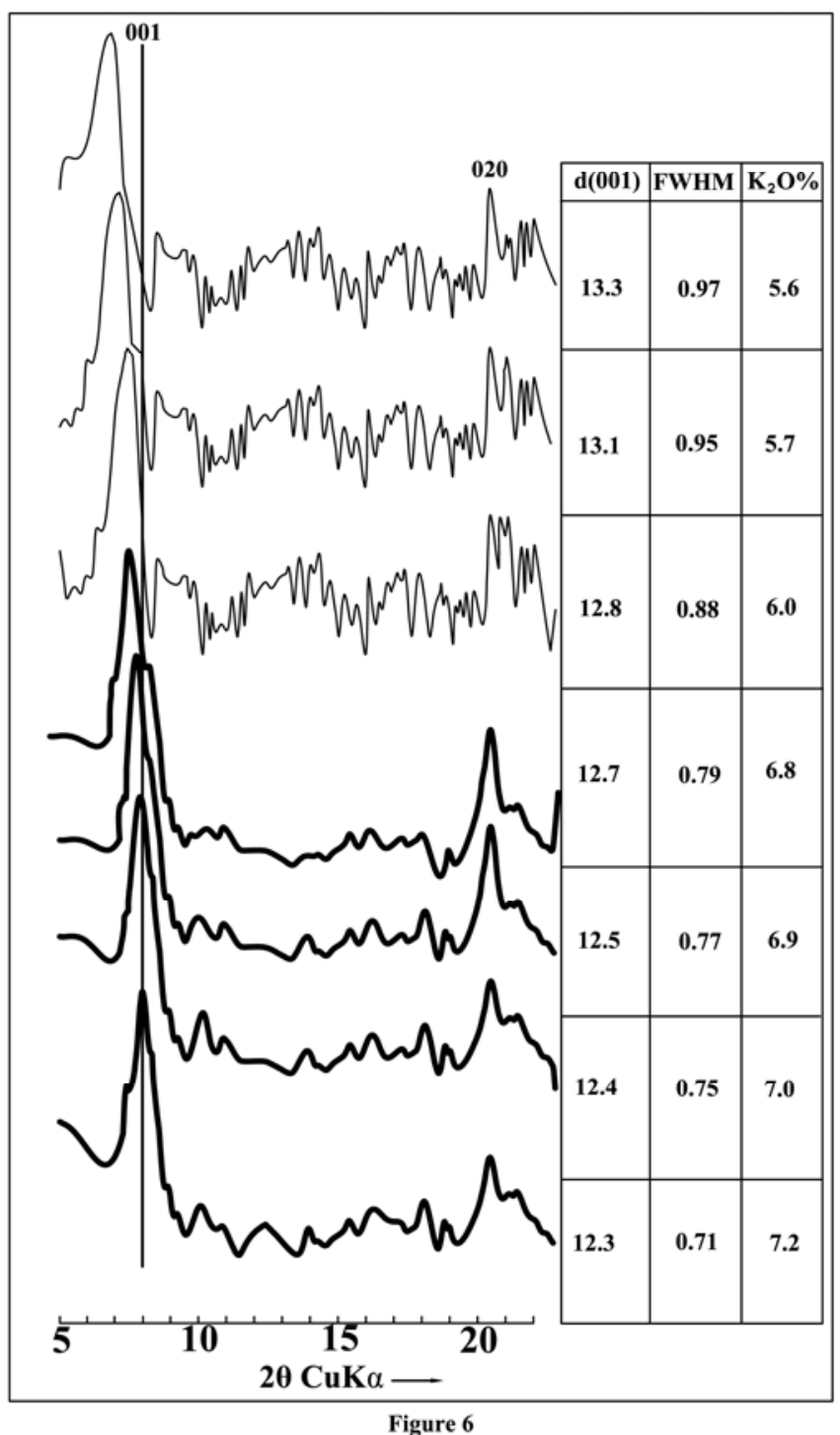




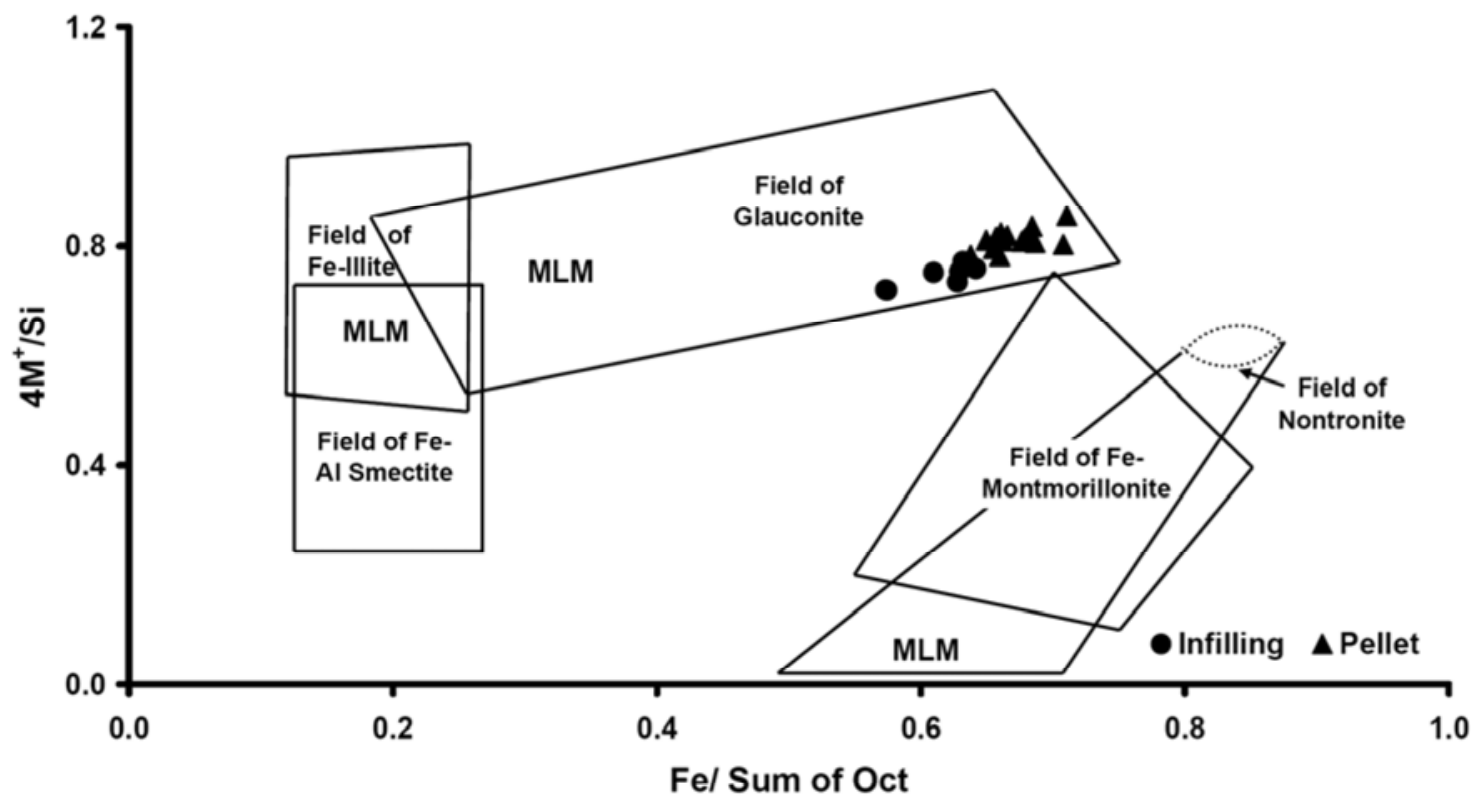

Figure 7

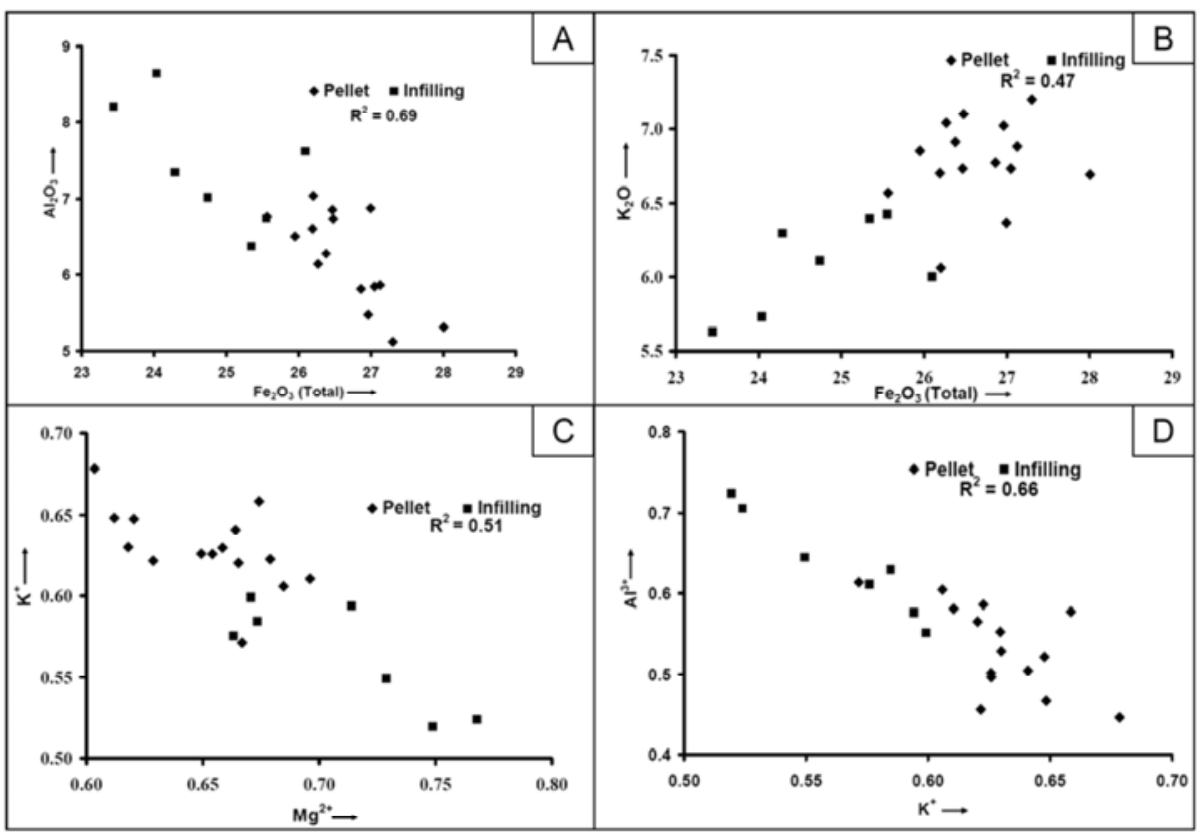

Figure 8 


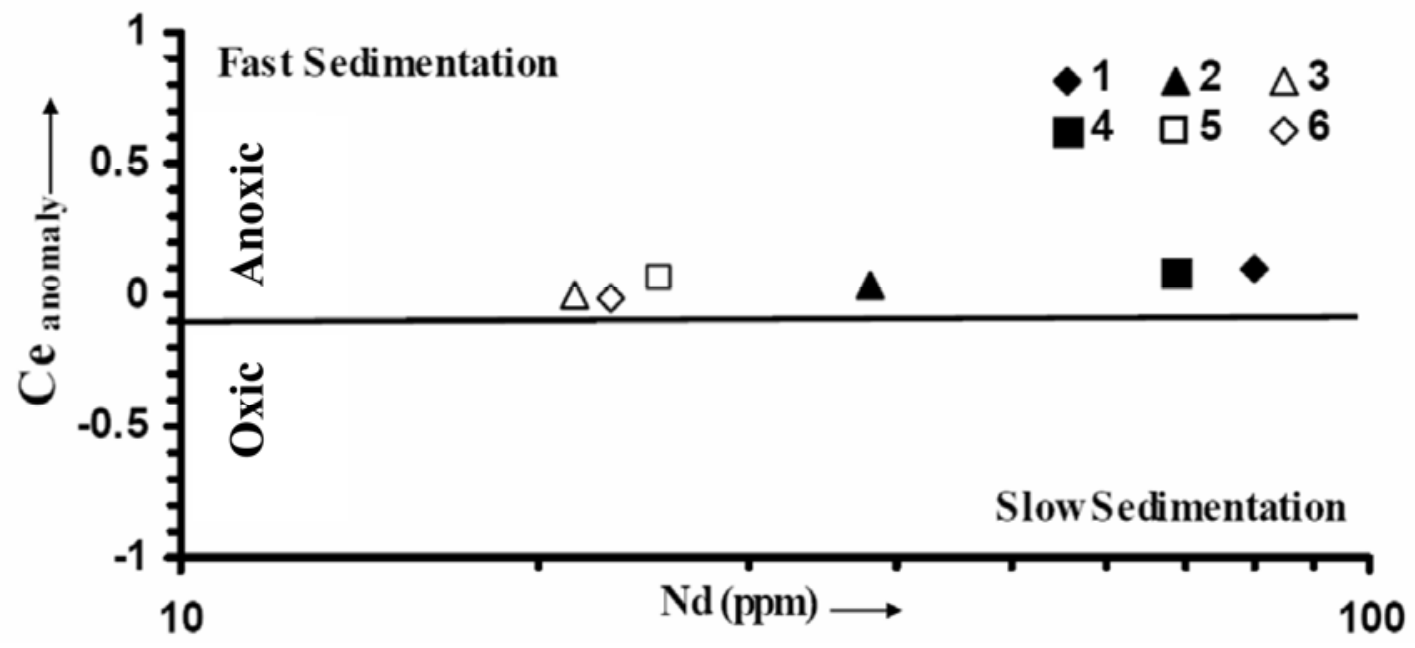

Figure 9

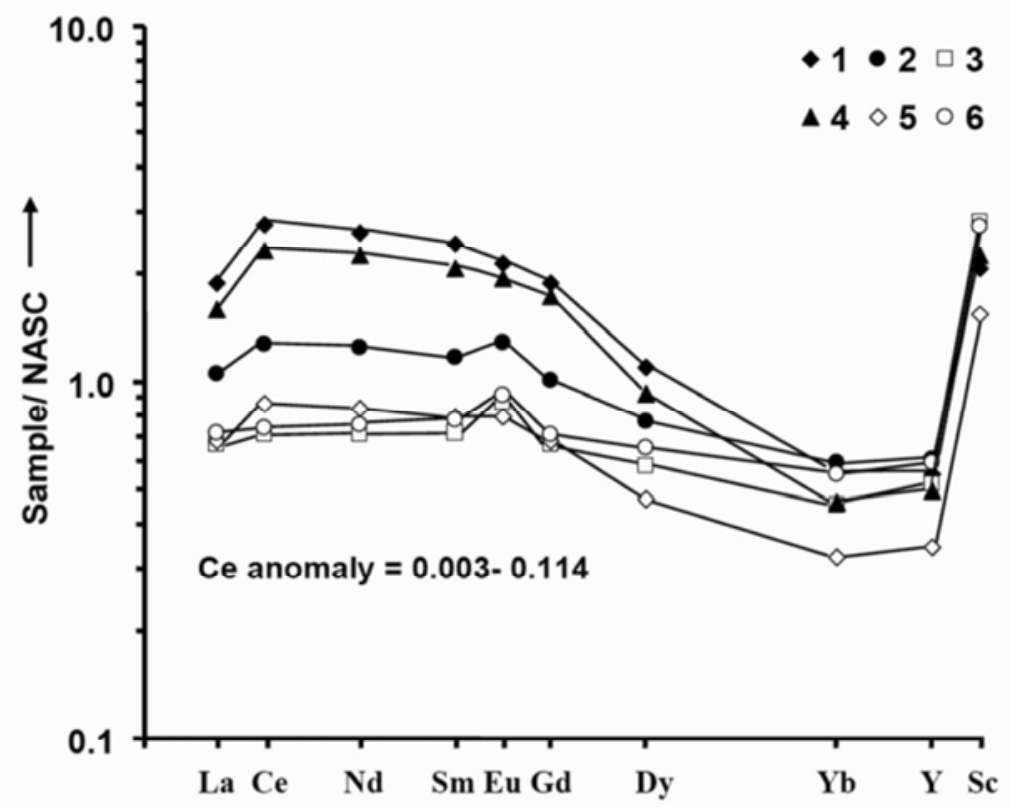

Figure 10 